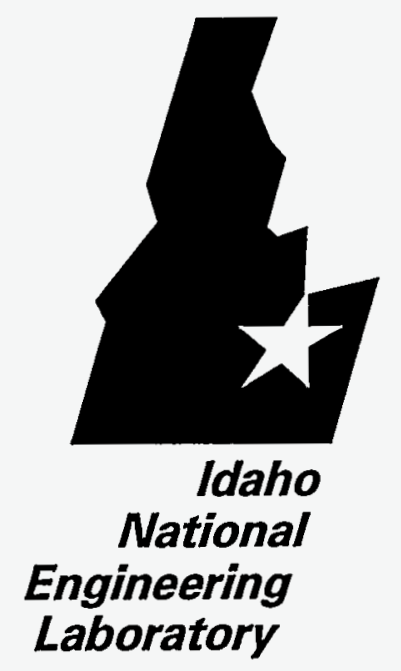

INEL-96/0186

April 1996

\title{
ICPP Environmental Monitoring Report CY-1995
}

\author{
RECEIVED \\ JUL $2^{9} 1996$ \\ OSTI
}

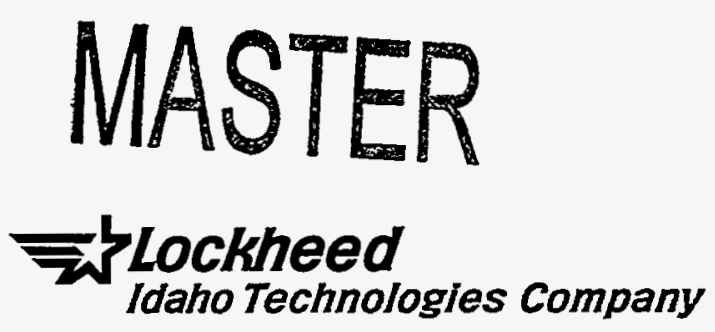





\section{ICPP Environmental Monitoring Report CY-1995}

Published April 1996

\section{Idaho National Engineering Laboratory Environmental Protection Department Lockheed Idaho Technologies Company Idaho Falls, Idaho 83415}

Prepared for the

U.S. Department of Energy Assistant Secretary for Environmental Management Under DOE Idaho Operations Office

Contract DE-AC07-94ID13223 


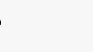




\section{DISCLAIMER}

Portions of this document may be illegible in electronic image products. Images are produced from the best available original document. 


\section{TABLE OF CONTENTS}

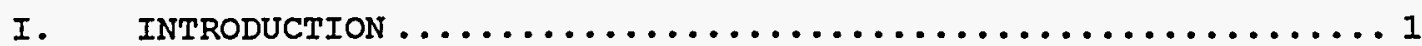

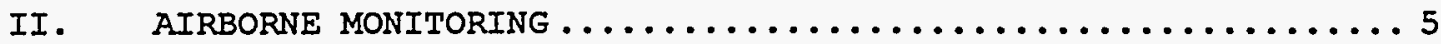

1. INTRODUCTION $\ldots \ldots \ldots \ldots \ldots \ldots \ldots \ldots \ldots \ldots \ldots \ldots \ldots$

2. AIRBORNE RELEASES TO THE ENVIRONMENT $\ldots \ldots \ldots \ldots \ldots \ldots \ldots$

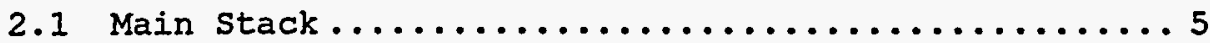

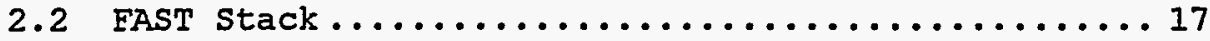

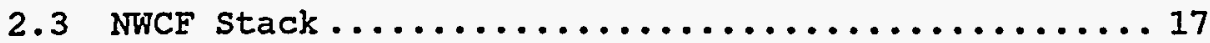

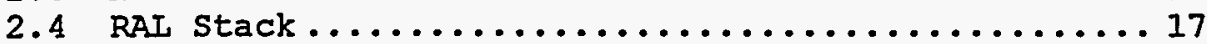

2.5 Coal Fired Steam Generating Facility (CFSGF) ..... 17

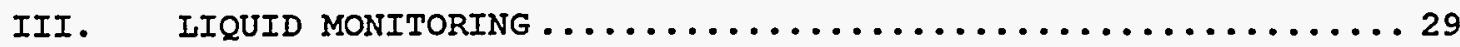

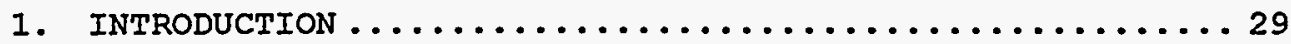

2. IIQUID RELEASES TO THE ENVIRONMENT $\ldots \ldots \ldots \ldots \ldots \ldots \ldots$

2.1 Service Waste system................... 29

2.2 Production and Potable Water Wells ...........40

2.3 Sewage Treatment Plant.................40

2.4 ICPP Injection Well $\ldots \ldots \ldots \ldots \ldots \ldots \ldots \ldots \ldots \ldots$

\section{FIGURES}

1-1. SUMMARY OF AIRBORNE RELEASES $\ldots \ldots \ldots \ldots \ldots \ldots \ldots \ldots \ldots \ldots$

1-2. SUMMARY OF IIQUID RELEASES $\ldots \ldots \ldots \ldots \ldots \ldots \ldots \ldots \ldots \ldots$

2-1. MAIN STACK EFFLUENT - Total Activity $\ldots \ldots \ldots \ldots \ldots \ldots \ldots$

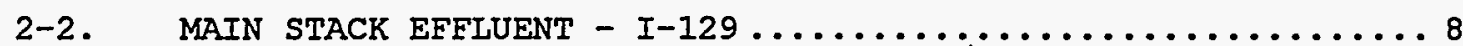

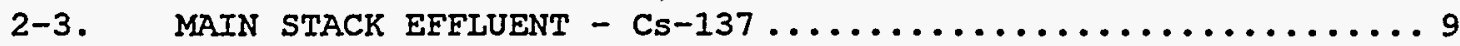

2-4. MAIN STACK EFFLUENT - Sr-90....................... 10

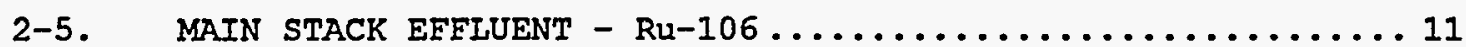

2-6. MAIN STACK EFELUENT - Pu-Total .................... 12

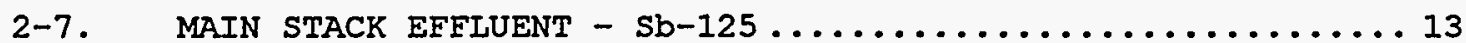

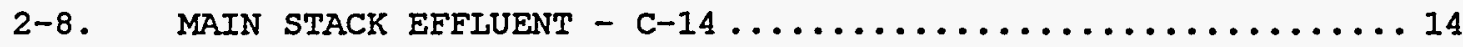

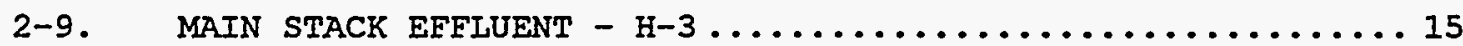

2-10. NO $\mathrm{NO}_{x}$ RELEASES FROM ICPP MAIN $\operatorname{STACK} \ldots \ldots \ldots \ldots \ldots \ldots \ldots \ldots \ldots$ 
2-11. FAST STACK EFELUENT - Total Activity $\ldots \ldots \ldots \ldots \ldots \ldots \ldots$

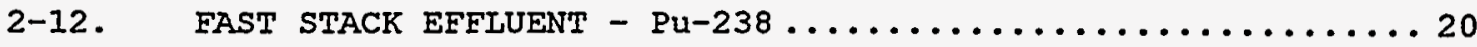

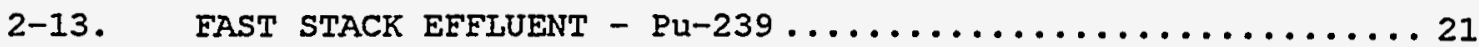

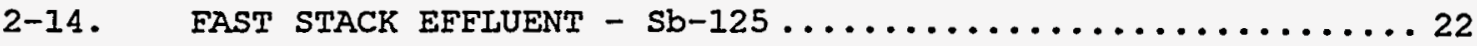

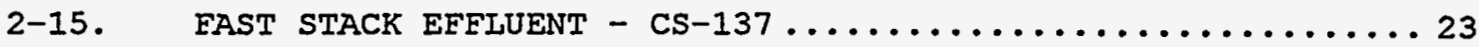

2-16. NWCF STACK EFFLUENT - Total Activity $\ldots \ldots \ldots \ldots \ldots \ldots \ldots$

2-17. RAI STACK EFFLUENT - Total Activity $\ldots \ldots \ldots \ldots \ldots \ldots \ldots \ldots \ldots \ldots \ldots$

3-1. SERVICE WASTE EFFLUENT - Total Activity $\ldots \ldots \ldots \ldots \ldots \ldots 33$

3-2. SERVICE WASTE EFFLUENT $-\mathrm{Pu}-238 \ldots \ldots \ldots \ldots \ldots \ldots \ldots \ldots \ldots \ldots \ldots \ldots$

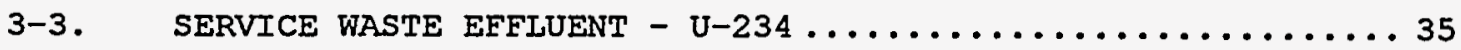

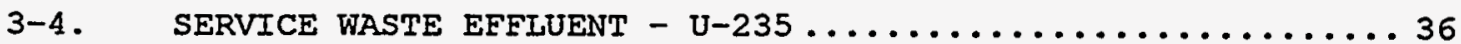

3-5. SERVICE WASTE EFFLUENT $-\mathrm{U}-238 \ldots \ldots \ldots \ldots \ldots \ldots \ldots \ldots \ldots \ldots \ldots \ldots$

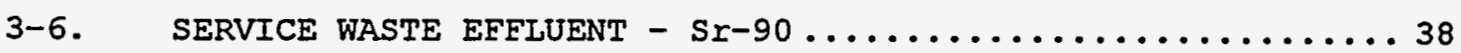

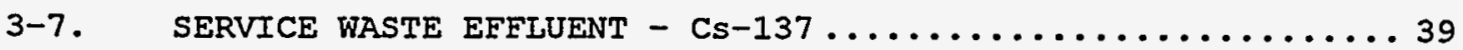

3-8. SEWAGE TREATMENT PLANT - BOD, BOD Efficiency ..........44

3-9. SEWAGE TREATMENT PLANT - Do $\ldots \ldots \ldots \ldots \ldots \ldots \ldots \ldots \ldots \ldots \ldots$

3-10. SEWAGE TREATMENT PLANT $-\mathrm{pH} \ldots \ldots \ldots \ldots \ldots \ldots \ldots \ldots \ldots \ldots \ldots \ldots$

3-11. SEWAGE TREATMENT PIANT - Volume $\ldots \ldots \ldots \ldots \ldots \ldots \ldots \ldots \ldots$

\section{TABLES}

1-1. SUMMARY OF RELEASE DATA FOR $1995 \ldots \ldots \ldots \ldots \ldots \ldots \ldots \ldots \ldots$

2-1. AIRBORNE RELEASES FROM ICPP MAIN STACK - CY-1995 ........6

2-2. AIRBORNE RELEASES FROM ICPP FAST STACK - CY-1995 ........ 18

2-3. AIRBORNE RELEASES FROM ICPP NWCF STACK - CY-1995 ........ 24

2-4. AIRBORNE REIEASES FROM ICPP RAI STACK - CY-1995 ......... 26

2-5. COAL FIRED STEAM GENERATING FACILITY - CY-1995 ........ 28

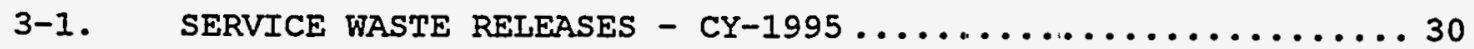

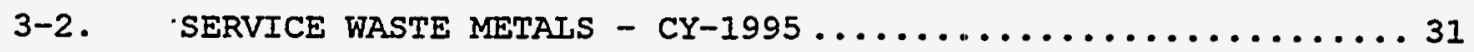


3-3. DCG RATIOS - DOE - CY-1995 ........................ 32

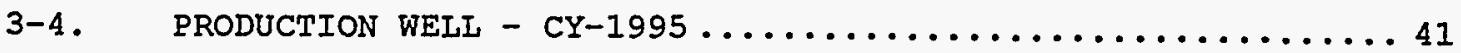

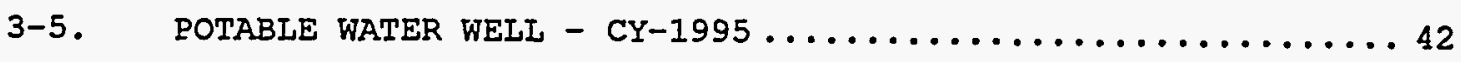

3-6. SEWAGE TREATMENT PLANT ANALYSIS - CY-1995 ............ 43

\section{DISCLAIMER}

This report was prepared as an account of work sponsored by an agency of the United States Government. Neither the United States Government nor any agency thereof, nor any of their employees, makes any warranty, express or implied, or assumes any legal liability or responsibility for the accuracy, completeness, or usefulness of any information, apparatus, product, or process disclosed, or represents that its use would not infringe privately owned rights. Reference herein to any specific commercial product, process, or service by trade name, trademark, manufacturer, or otherwise does not necessarily constitute or imply its endorsement, recommendation, or favoring by the United States Government or any agency thereof. The views and opinions of authors expressed herein do not necessarily state or reflect those of the United States Government or any agency thereof. 



\section{ACRONYM LIST}

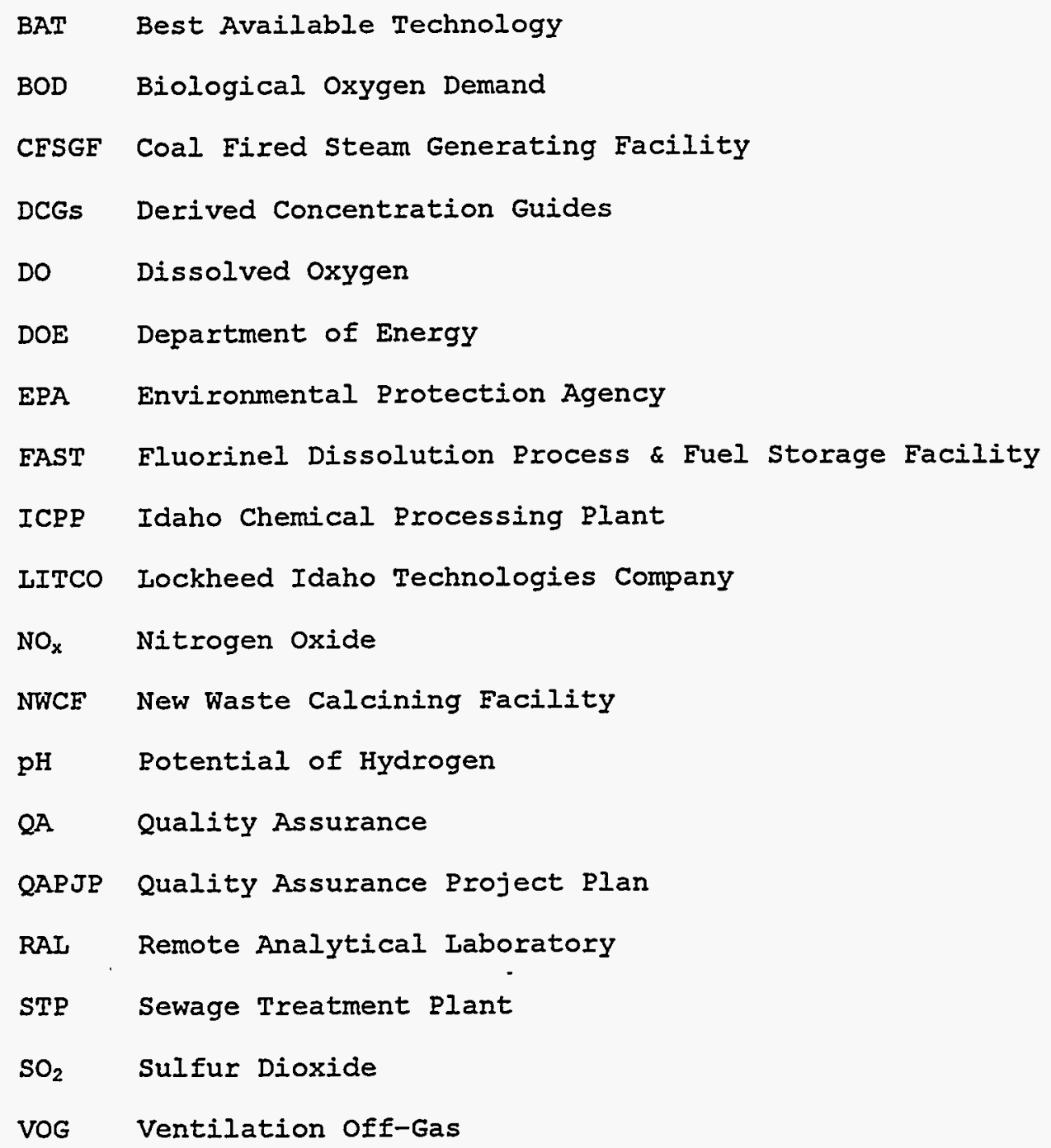





\section{ICPP ENVIRONMENTAL MONITORING REPORT 1995}

\section{INTRODUCTION}

Summarized in this report are the data collected through Environmental Monitoring programs conducted at the Idaho Chemical Processing Plant (ICPP) by the Environmental Protection Department. This report is published in response to DOE Order 5400.1.

The ICPP is responsible for complying with all applicable Eederal, state, Local and DOE Rules, Regulations and Orders. Radiological effluent and emissions are regulated by the DOE in accordance with the Derived Concentration Guides (DCGs) as presented in DOE Order 5400.5. The state of Idaho regulates nonradiological waste resulting from the ICPP operations including airborne, liquid, and solid waste.

The Environmental Department updated the Quality Assurance (QA) Project Plan for Environmental Monitoring activities during the third quarter of 1992 . $Q A$ activities have resulted in the ICPP's implementation of the Environmental Protection Agency (EPA) rules and guidelines pertaining to the collection, analyses, and reporting of environmentally related samples. Where no ERA methods for analyses existed for radionuclides, Lockheed Idaho Technologies Company (IITCO) methods were used.

Table 1-1 summarizes the volumes and activity released from ICPP stacks and liquid release points. Figure $1-1$ is a graphic representation of cumulative volume \& airborne releases and Figure 1-2 depicts cumulative volume \& liquid releases for the year. The graphs allow trends to be made of waste volume and activity released for the year. The Main stack gaseous monitor was not in operation for 1995. New Waste Calcining Facility (NWCF) was not in operation in 1995. During 1995 the cumulative airborne and liquid release of radionuclides was $2.20 \mathrm{E}-01$ curies. Airborne releases to the atmosphere contributed 4.53-04 curies and liquid effluent released to the Percolation Pond contributed 2.20E-01 curies. Liquid Effluent Treatment and Disposal (IET\&D) began operation on January 1, 1993. PEW condensates which previously were discharged to service waste are now treated in the IET\&D facility. Table 3-1 and 3-2 provide information on radionuclide activity and concentration of inorganic chemicals present in the service waste. The values are compared to regulatory limits where applicable. 
Table 1-1

SUMMMARY OF RELEASE DATA FOR 1995

AIRBORNE

$\begin{array}{cc}\text { Volume } & \text { Activity } \\ (\mathrm{E}+09 \mathrm{m3}) & \text { (curies) }\end{array}$

\begin{tabular}{|c|c|c|c|c|}
\hline Jan & $\begin{array}{l}\text { Month } \\
0.328\end{array}$ & $\begin{array}{l}\text { YTD } \\
0.328\end{array}$ & $\begin{array}{l}\text { Month } \\
9.64 \mathrm{E}-06\end{array}$ & $\begin{array}{c}\text { YTD } \\
9.64 E-06\end{array}$ \\
\hline Feb & 0.336 & 0.664 & 3.42E-05 & $4.38 \mathrm{E}-05$ \\
\hline Mar & 0.314 & 0.978 & $2.33 E-0 S$ & $6.71 E-05$ \\
\hline Apr & 0.360 & 1.338 & $3.13 \mathrm{E}-05$ & $9.84 \mathrm{E}-05$ \\
\hline May. & 0.322 & 1.660 & $5.18 \mathrm{E}-05$ & $1.50 \mathrm{E}-04$ \\
\hline Jun & 0.339 & 1.999 & $2.19 \mathrm{E}-05$ & $1.72 \mathrm{E}-04$ \\
\hline Jul & 0.276 & 2.275 & $8.54 \mathrm{E}-05$ & $2.58 \mathrm{E}-04$ \\
\hline Ang. & 0.320 & 2.595 & $3.73 E-05$ & $2.95 E-04$ \\
\hline Sep. & 0.398 & 2.993 & $1.10 \mathrm{E}-04$ & $4.05 \mathrm{E}-04$ \\
\hline Oet & 0.388 & 3.381 & $1.66 \mathrm{E}-05$ & $4.21 \mathrm{E}-04$ \\
\hline Noy & 0.362 & 3.743 & $193 \mathrm{E}-0 \mathrm{~S}$ & $4.41 \mathrm{E}-04$ \\
\hline Dec & 0.360 & 4.103 & $1.24 \mathrm{E}-05$ & $4.53 \mathrm{E}-04$ \\
\hline
\end{tabular}

LIOUID

Volume

(E+09 L)

Activity

(curies)

\begin{tabular}{|c|c|c|c|}
\hline $\begin{array}{l}\text { Month } \\
0.150\end{array}$ & $\begin{array}{r}\text { YTD } \\
0.150 \\
\end{array}$ & $\begin{array}{l}\text { Month } \\
5.02 \mathrm{E}-04\end{array}$ & $\begin{array}{c}\text { YTD } \\
5.02 \mathrm{E}-04\end{array}$ \\
\hline 0.154 & 0.304 & $4.64 \mathrm{E}-04$ & $9.66 \mathrm{E}-04$ \\
\hline 0.144 & 0.448 & $1.49 \mathrm{E}-03$ & $2.46 \mathrm{E}-03$ \\
\hline 0.220 & 0.668 & $2.65 \mathrm{E}-03$ & $5.11 E-03$ \\
\hline 0.174 & 0.842 & $3.21 E-03$ & $8.32 \mathrm{E}-03$ \\
\hline 0.136 & 0.978 & $5.31 E-04$ & $8.85 \mathrm{E}-03$ \\
\hline 0.135 & 1.113 & $1.33 \mathrm{E}-03$ & $1.02 E-02$ \\
\hline 0.171 & 1.284 & 8.50E-04 & $1.10 \mathrm{E}-02$ \\
\hline 0.143 & 1.427 & $1.03 \mathrm{E}-04$ & 1.11E-02 \\
\hline 0.170 & 1.597 & $1.21 E-01$ & $1.32 \mathrm{E}-01$ \\
\hline 0.138 & 1.735 & $3.53 \mathrm{E}-04$ & $1.32 \mathrm{E}-01$ \\
\hline 0.145 & 1.880 & $8.79 E-02$ & $2.20 \mathrm{E}-01$ \\
\hline
\end{tabular}


Figure 1-1

AIRBORNE RELEASES

CY-1995

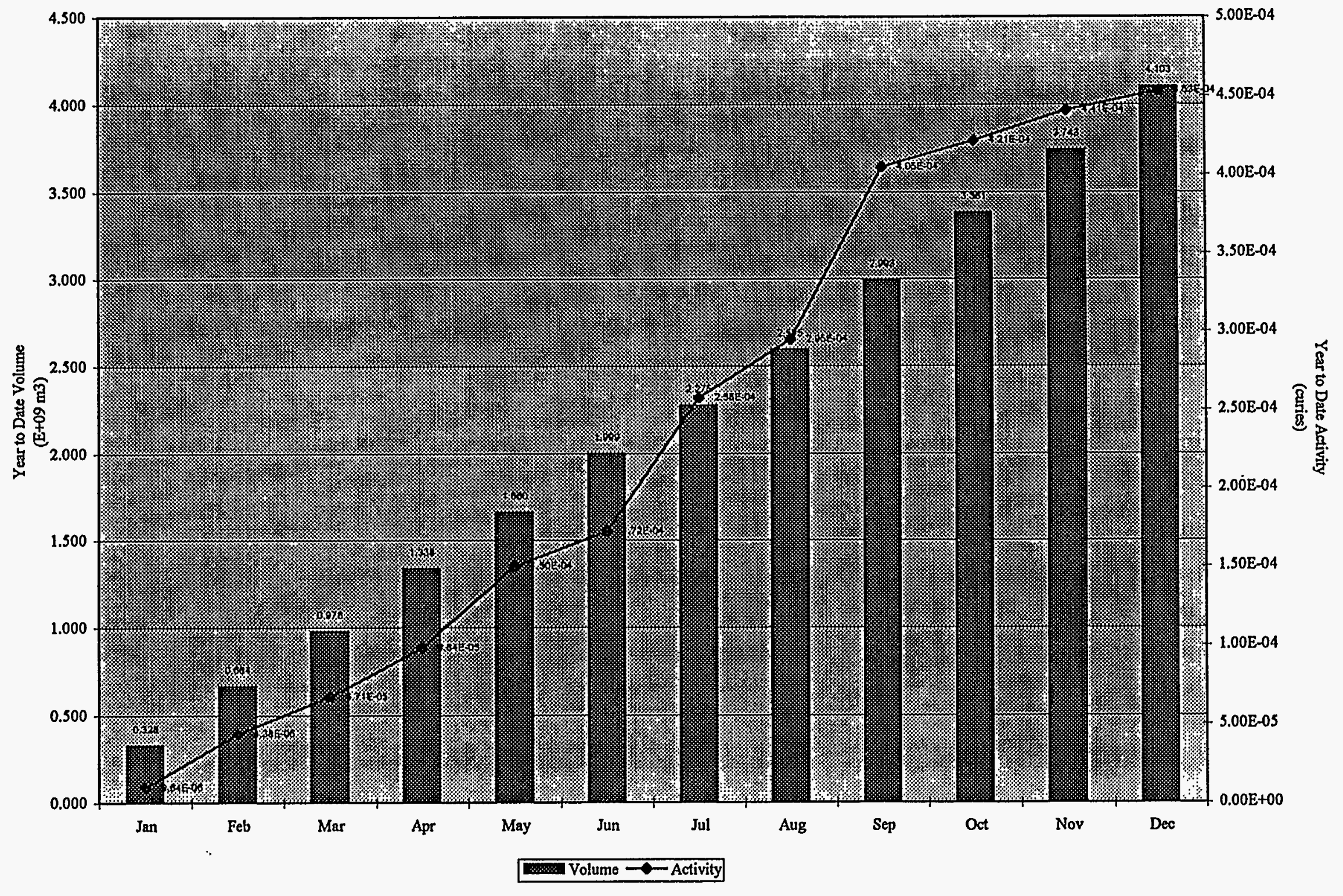


Figure 1-2

LIQUID EFFLUENT RELEASES

CY-1995

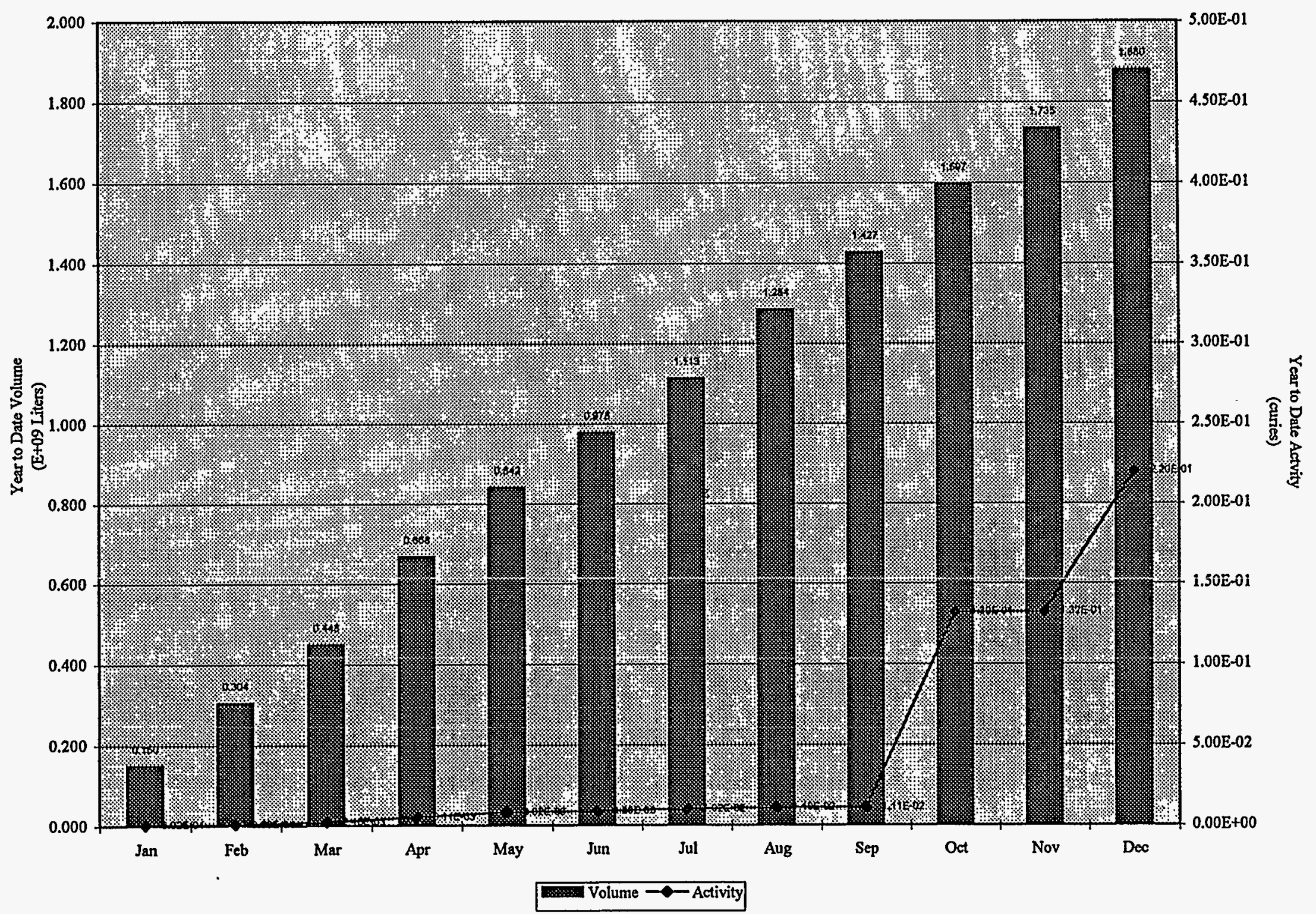




\section{INTRODUCTION}

Airborne radioactive emissions are monitored from the Main stack (CPP-708), the Fluorinel Dissolution Process and Fuel storage Facility (FAST) Stack (CPP767), the New Waste Calcining Facility (NWCF) Stack (CPP-659), and the Remote Analytical Laboratory (RAL) Stack (CPP-684). NWCF was not in operation in 1995.

The Main Stack is equipped with radiological particulate and gaseous monitoring systems and the FAST Stack is equipped with a particulate monitoring system. The Main stack gaseous monitor was not in operation in 1995. The airborne monitoring systems are based upon a proportional isokinetic sample. Particulate filters are collected and analyzed daily on the Main stack. Nitrogen oxide $\left(\mathrm{NO}_{\mathrm{x}}\right)$ emissions are the only nonradioactive airborne contaminant that is monitored from the Main Stack.

Particulate filters for the RAI stack and FAST stack are pulled and analyzed monthly. The NWCF HVAC stack monitor filters are collected weekly and the Ventilation off-Gas (VOG) system is continuously monitored for radioactive particulates. The CFSGF is monitored for $\mathrm{NO}_{x}, \mathrm{SO}_{2}$, carbon monoxide, and opacity in accordance with the state of Idaho, the EPA and the DOE-ID.

Radioactive releases for each emission point were well below the DOE DCGs for 1995. DCGs at the INEL boundary are reference values for conducting radiological environmental protection programs at operational DOE facilities and sites.

Quality assurance objectives for data measurement and laboratory performance are listed in the Quality Assurance Project Plan (QAPJP-001) for the Analysis of the Environmental Samples by both the LITCO CPP Analytical Labs and Radiation and Radioanylitcal Chemistry. Final data reduction is performed by the Environmental Support section of the Environmental Protection Department.

\section{AIRBORNE RELEASES TO THE ENVIRONMENT}

\subsection{Main Stack}

Airborne radioactive release data from the Main stack for each month and the year are given in Table 2-1. This information is presented graphically in Figure 2-1. Graphic presentations showing yearly trends for radionuclides most likely to be present (iodine-129, cesium-137, strontium90, ruthenium-106, plutonium (total), antimony-125, $\mathrm{C}-14$, and $\mathrm{H}-3$ ), are given, is Figures 2-2 through 2-9, respectively. I-129, C-14, and $\mathrm{H}-3$ will have no results reported for 1994 and 1995 because the gaseous monitor was not in operation. Also NWCF was not in operation during 1995 so no releases for those radionuclides are apparent.

Nitrogen oxide $\left(\mathrm{NO}_{x}\right)$ emission from the Main stack is the only nonradioactive airborne contaminant continuously monitored. $\mathrm{NO}_{\mathbf{x}}$ concentration levels, while they do not violate any ambient air quality standard, must not exceed limits imposed by the FPR PSD permit. The limits set for the Main stack are 472 pounds per hour and 1700 tons per year. Figure 2-10 provides $\mathrm{NO}_{\mathrm{x}}$ emissions for the last three years. The total $\mathrm{NO}_{\mathrm{x}}$ released in 1995, was 0 tons. 


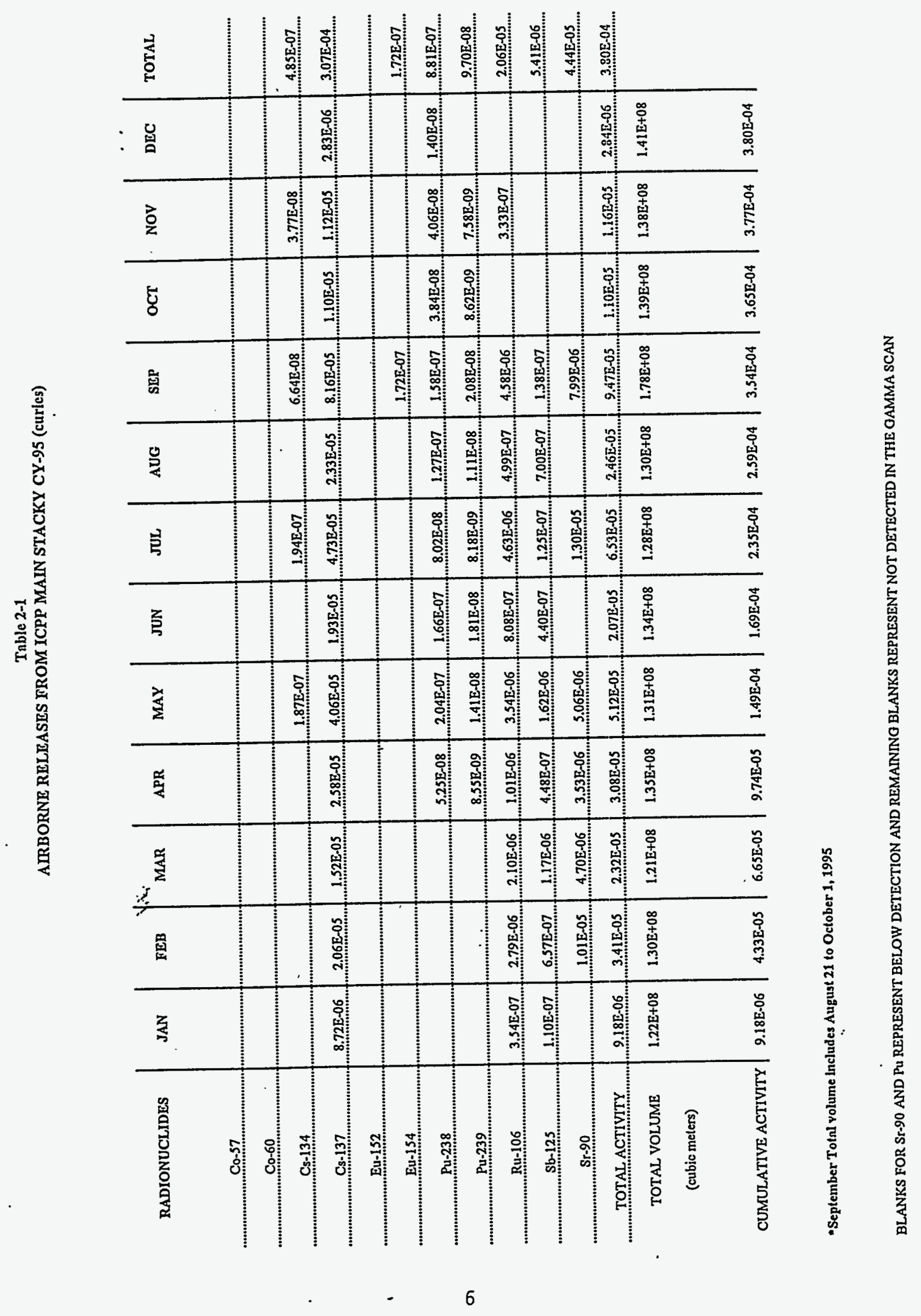




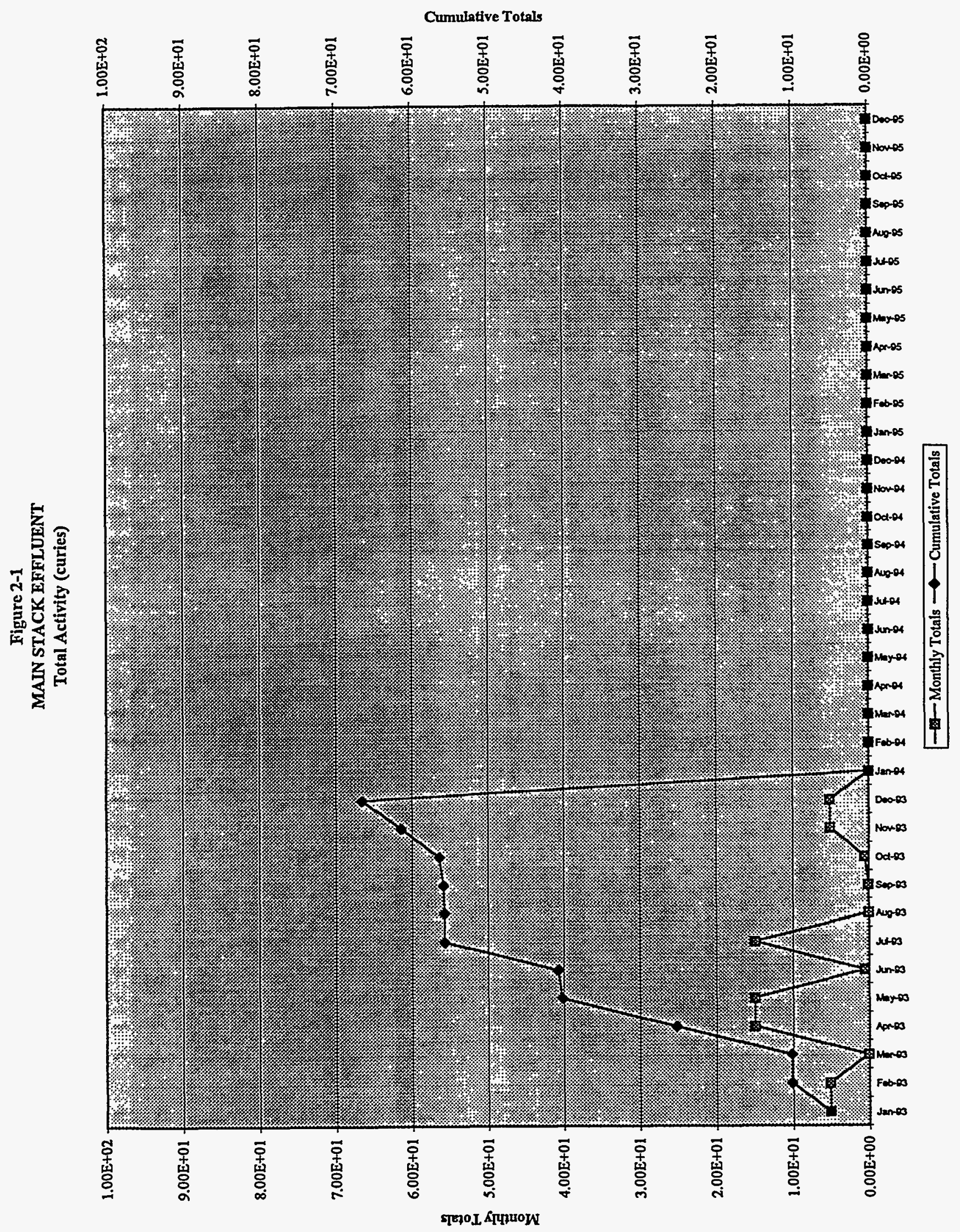




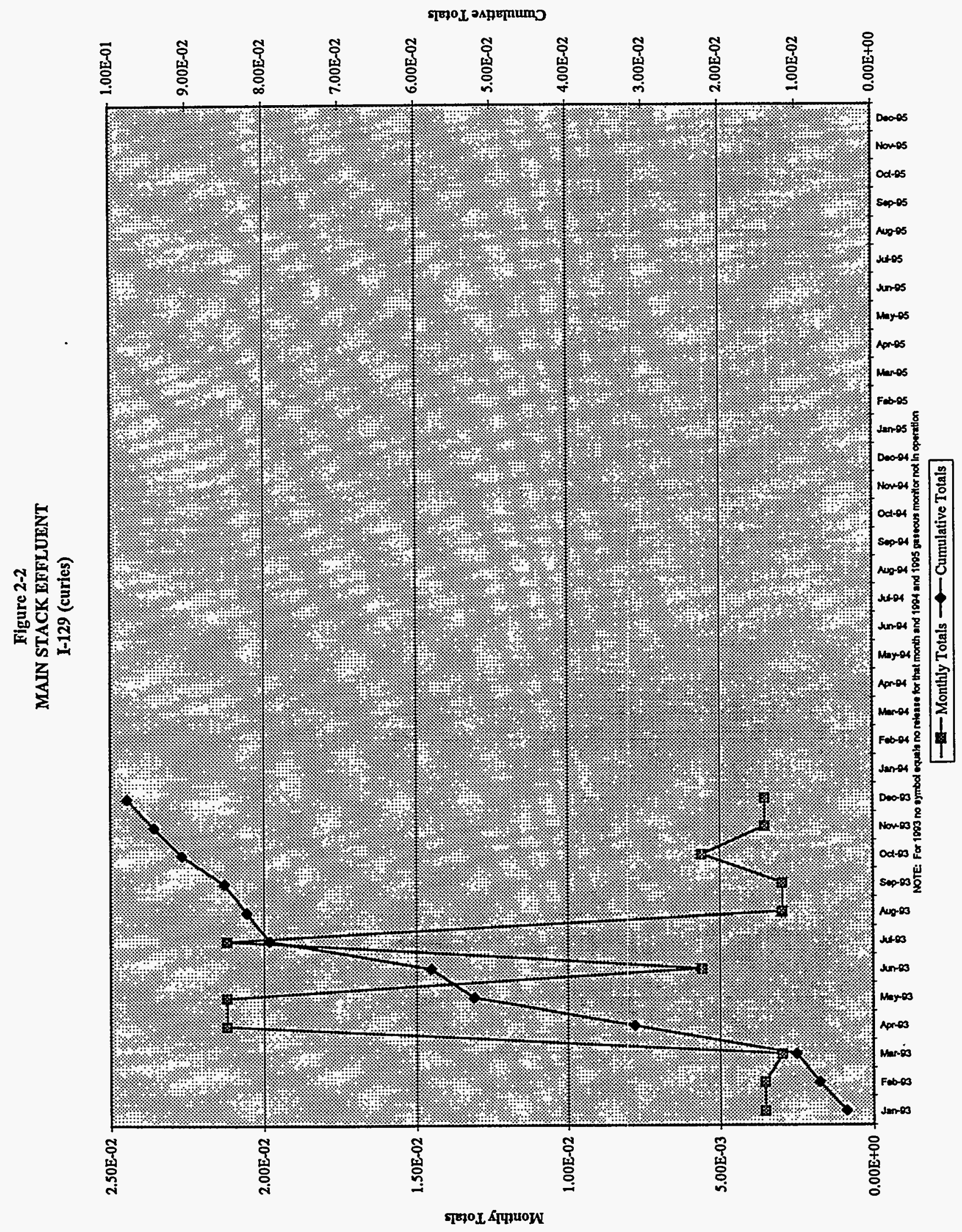




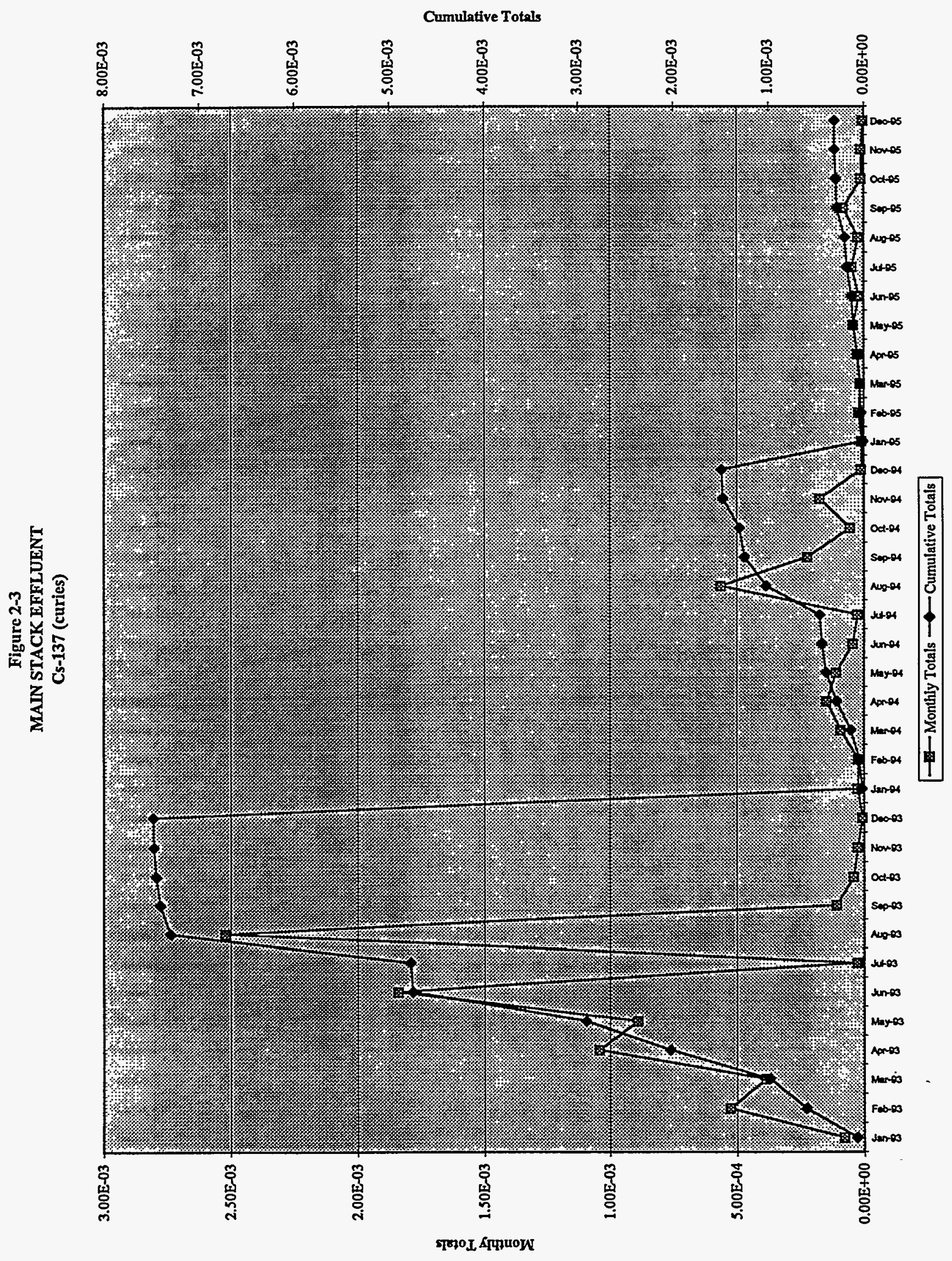


Figure 2-4

MAIN STACK EFFLUENT

Sr-90 (curies)

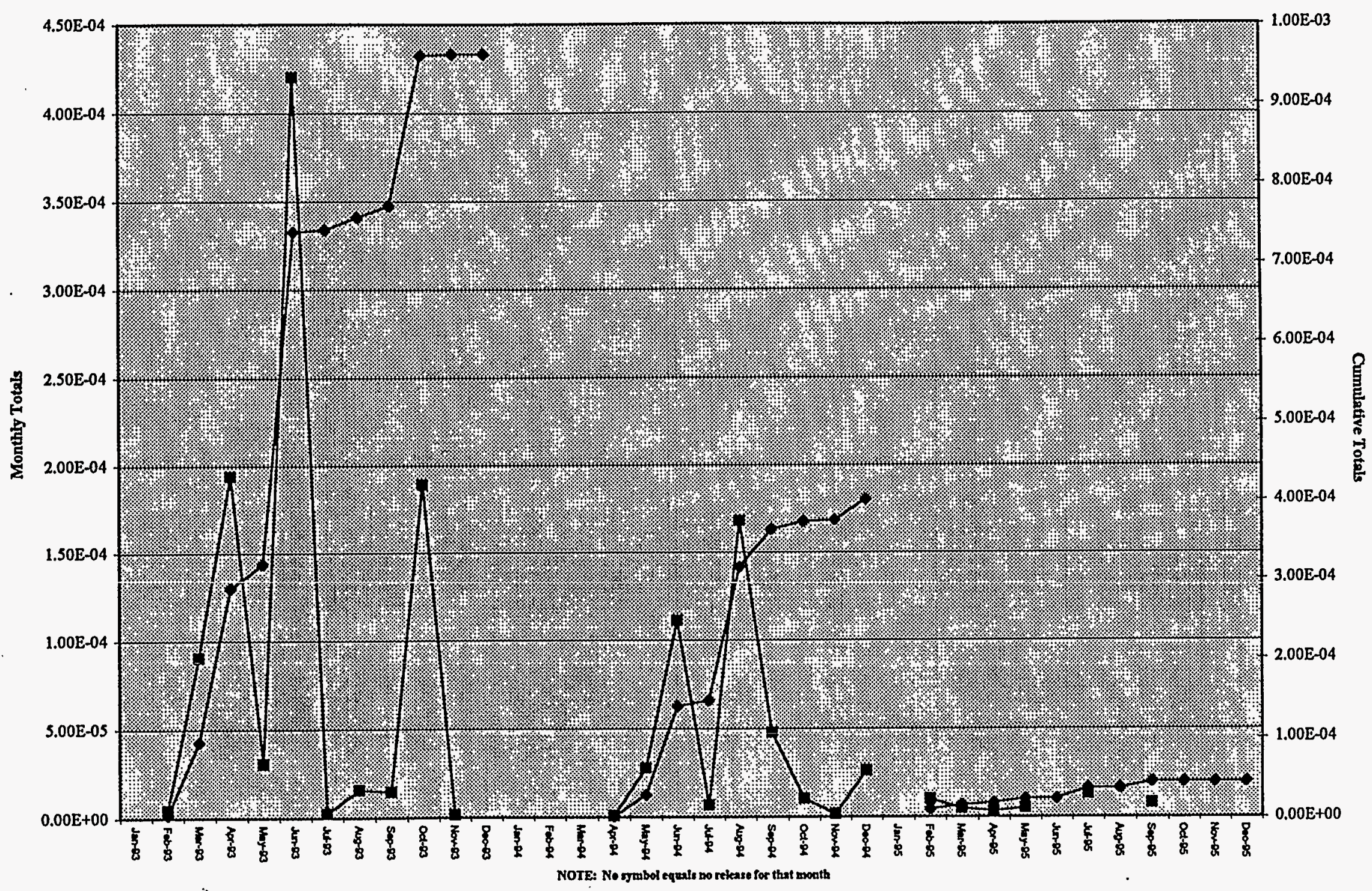

$\rightarrow-$ Monthly Totals $\rightarrow-$ Cumulative Totals 
Figure 2-5

MAIN STACK EFFLUENT

Ru-106 (curies)

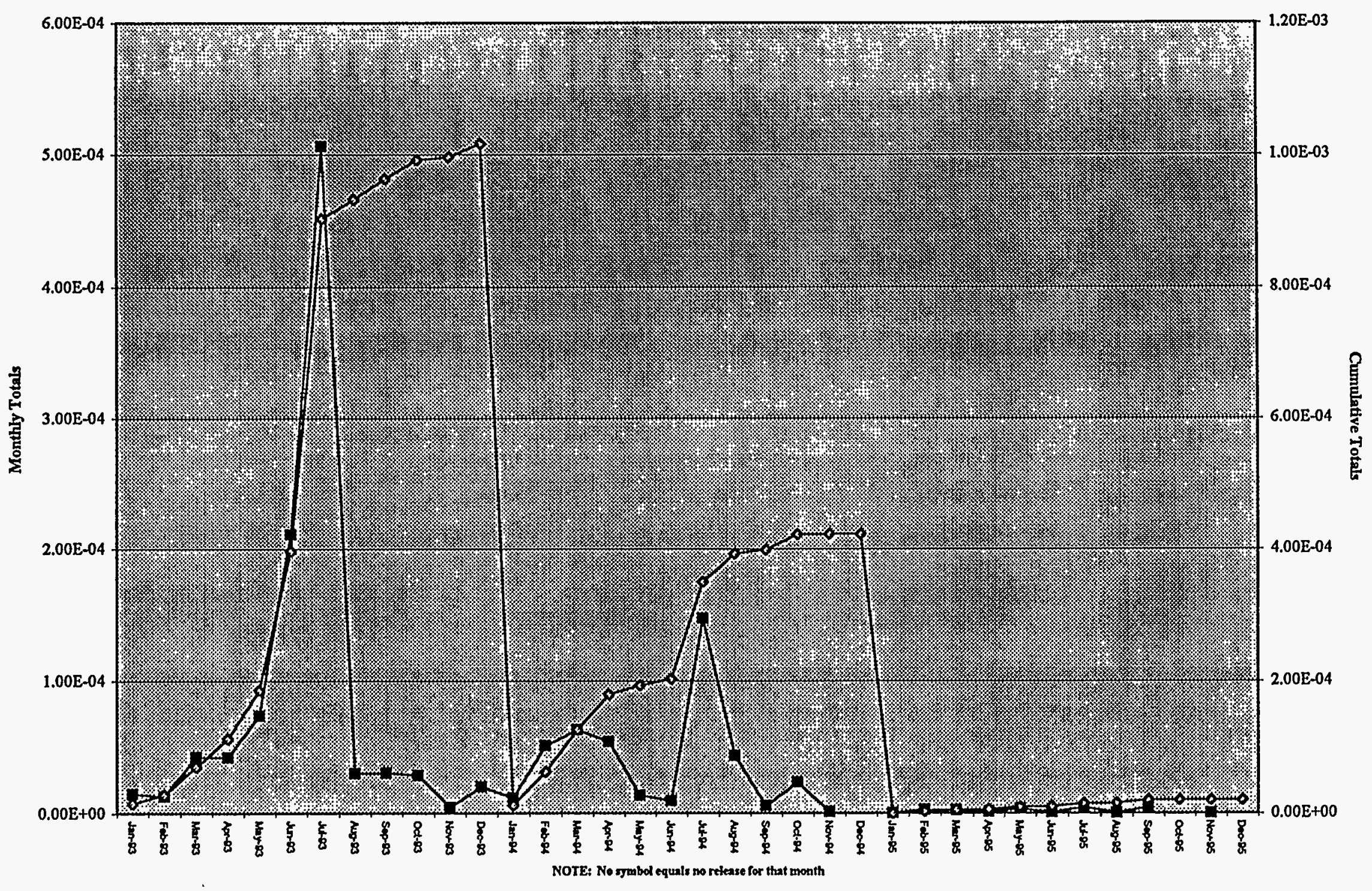

Momthly Totals $-0-$ Cumulative Totals 


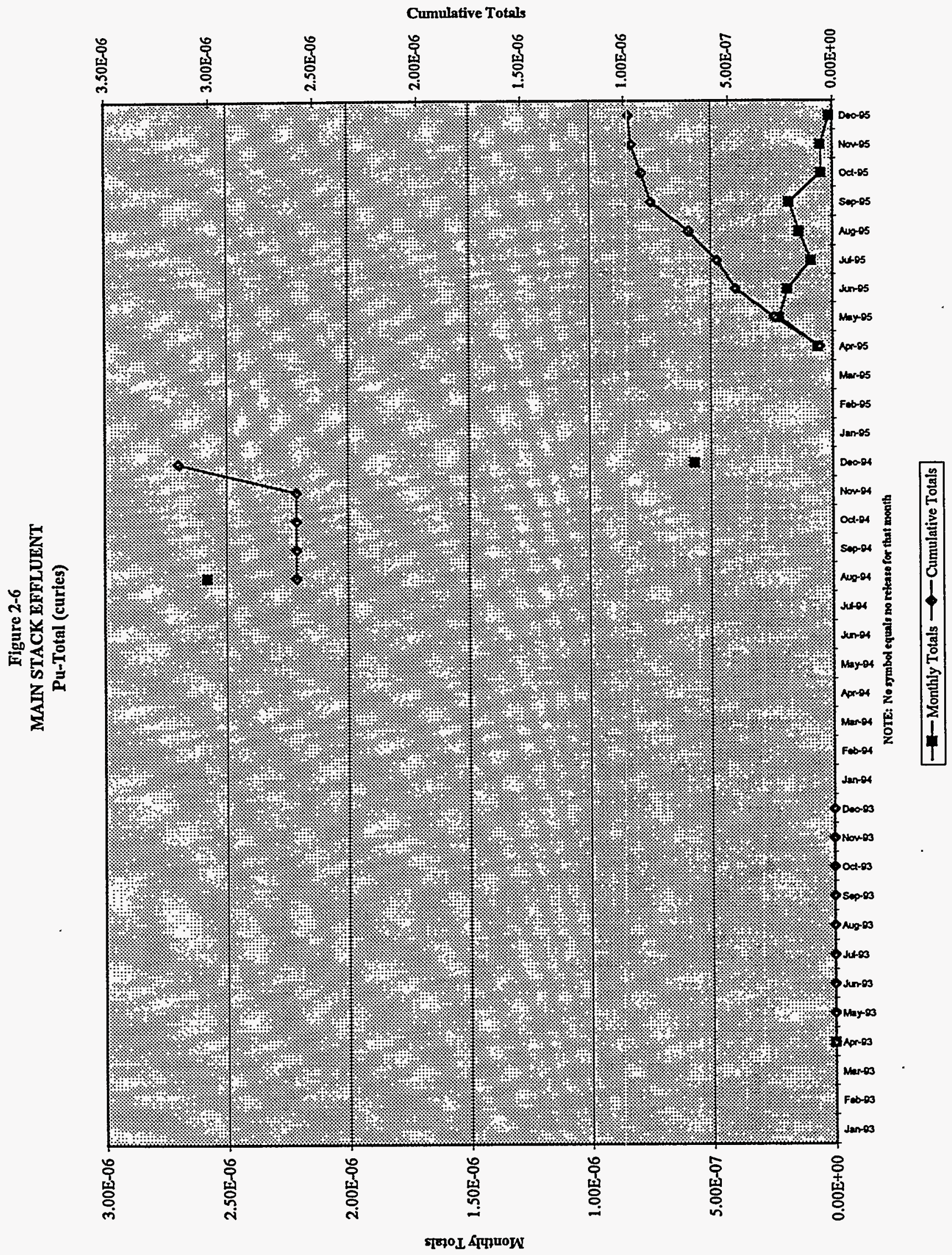




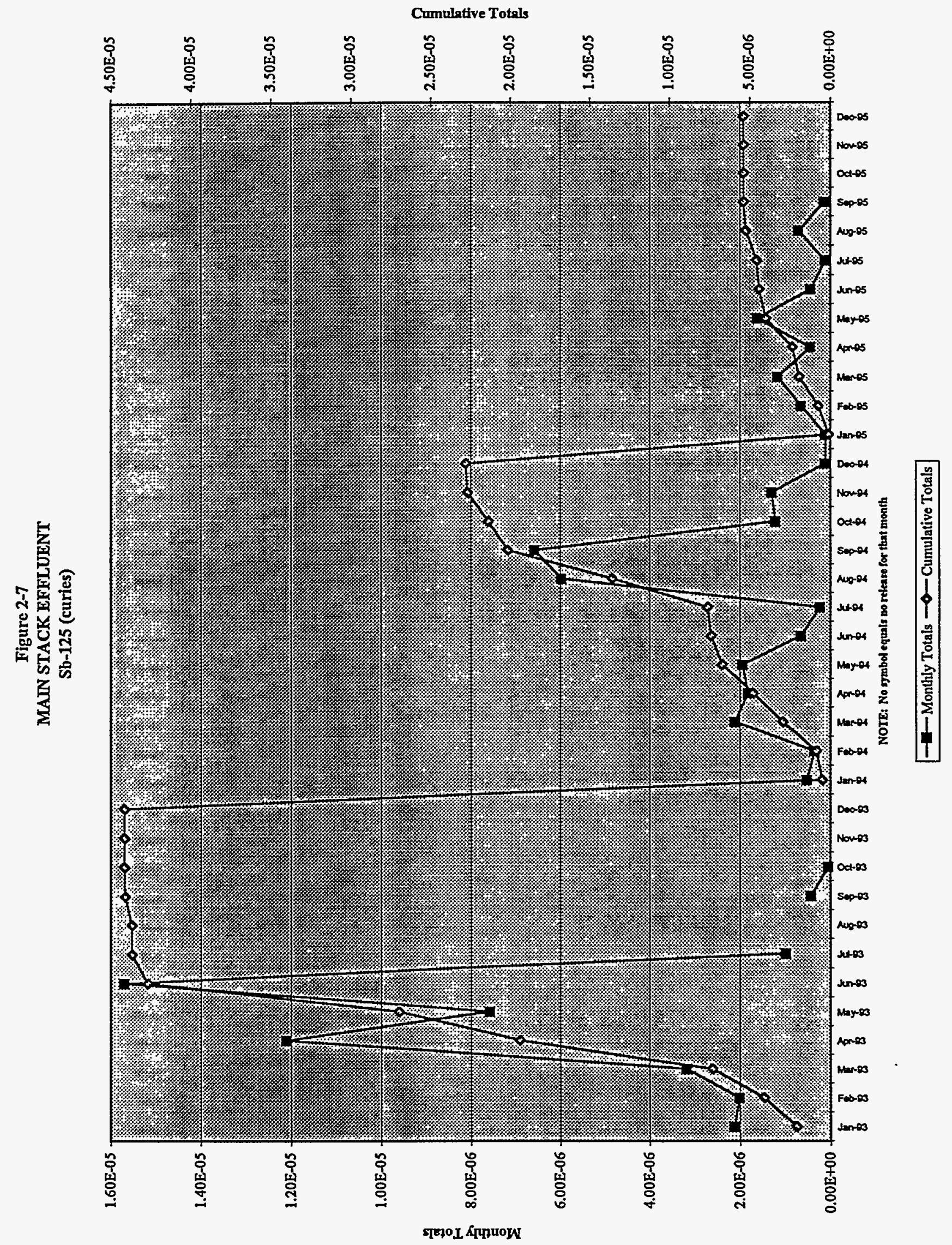




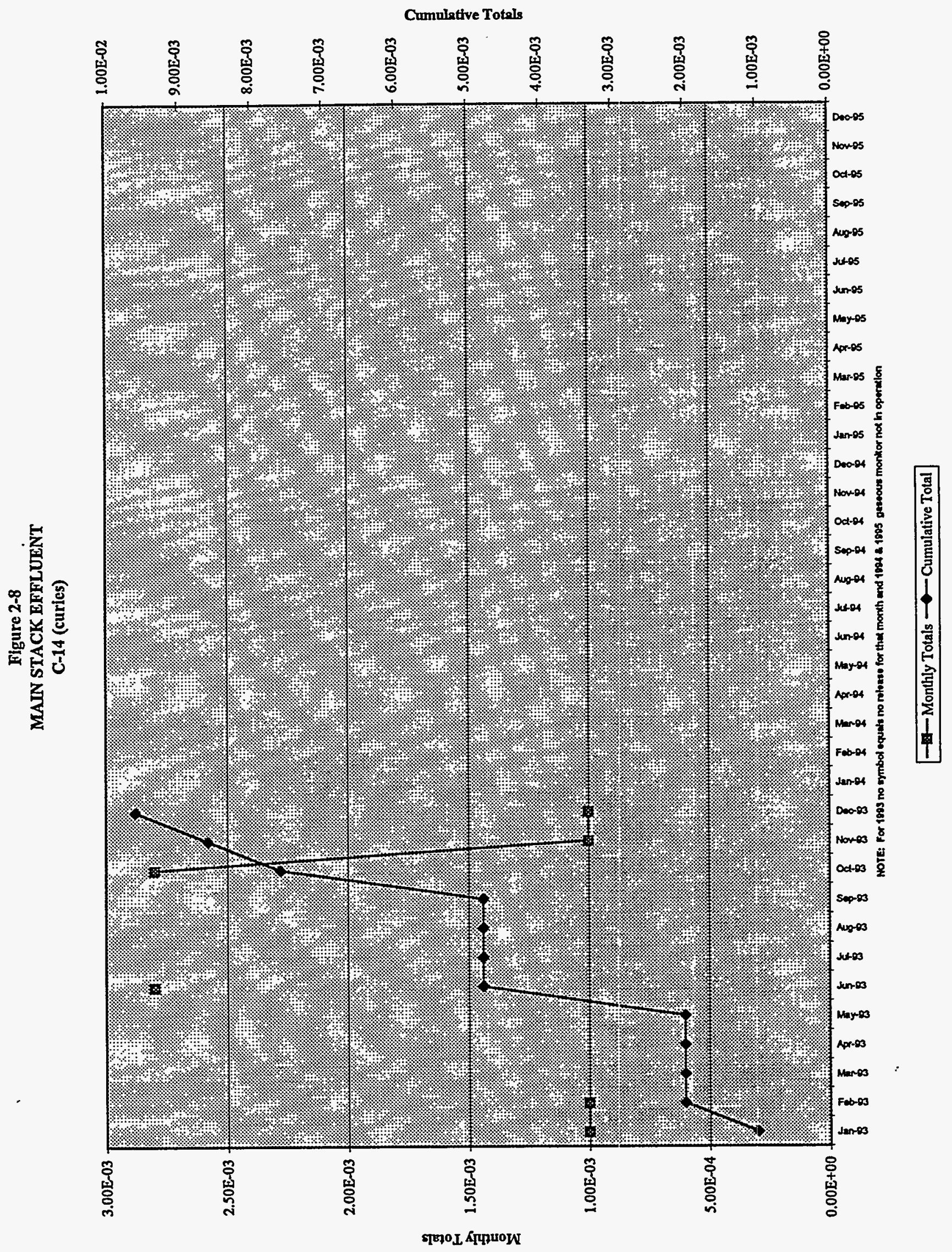




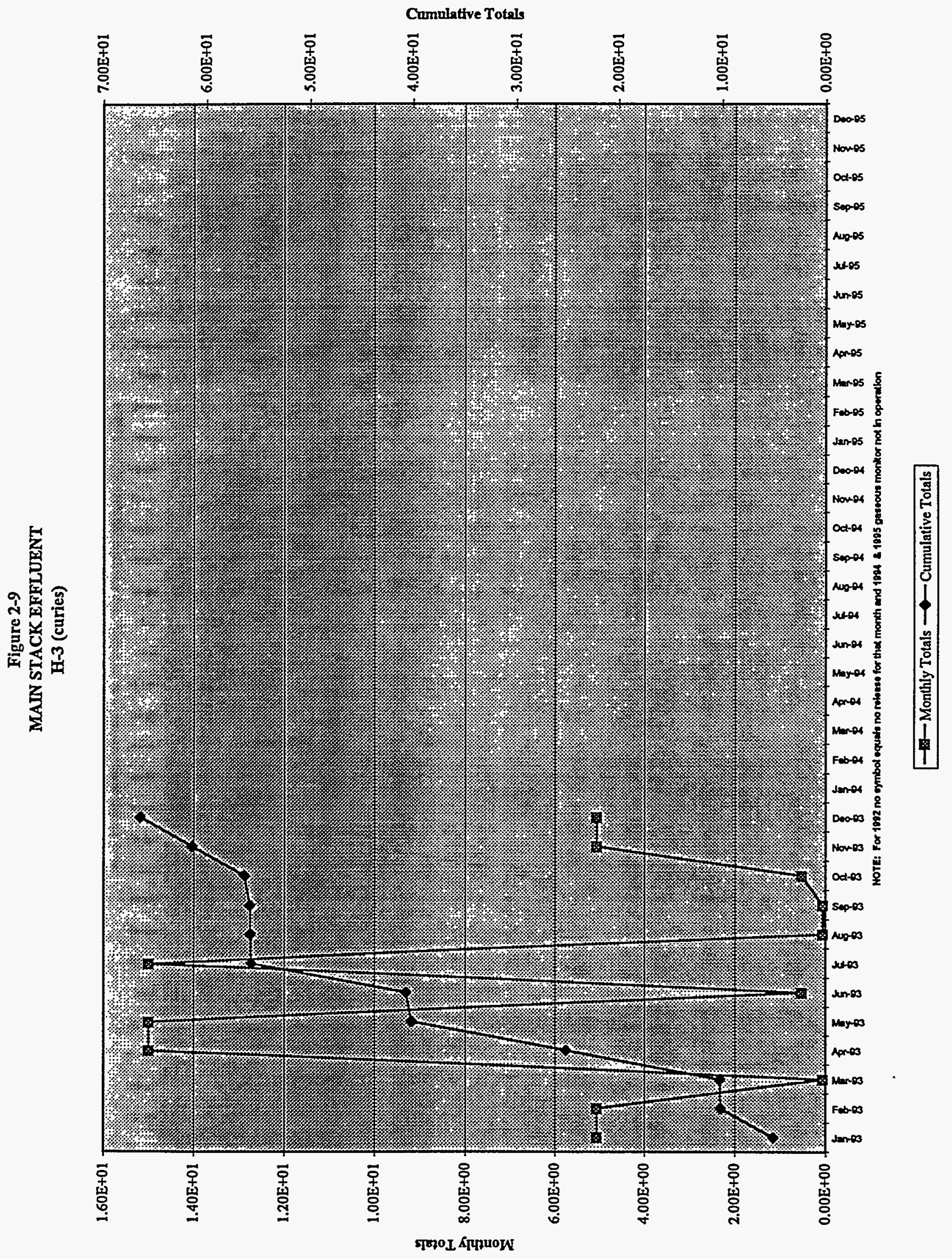




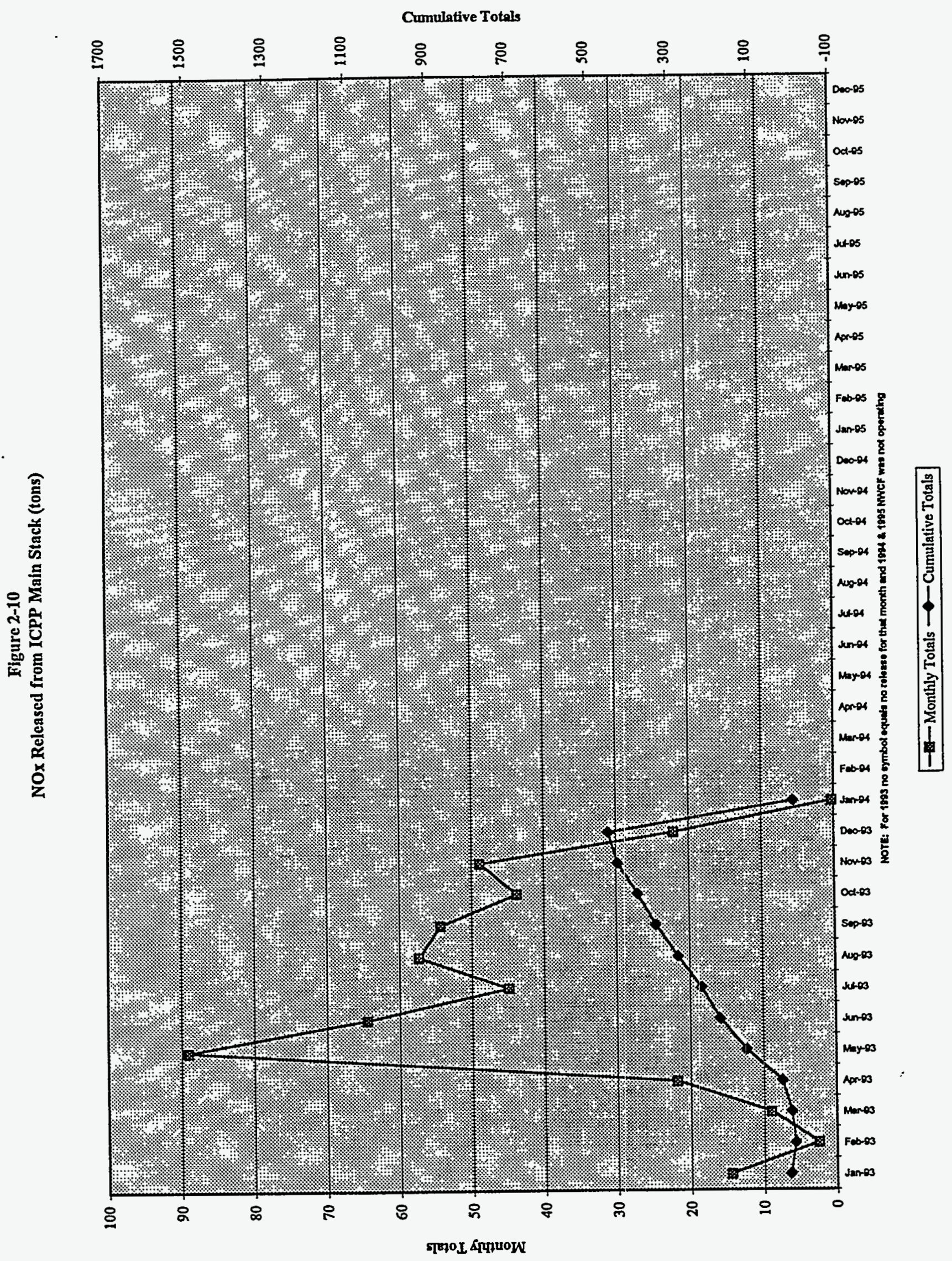


Table 2-2 lists the total radionuclide releases in curies from the FAST Stack per month by radionuclide and Figure 2-1I depicts the total monthly activity. Graphic presentations for plutonium 238, plutonium 239, antimony-125, and cesium 137 showing yearly trends are given in Figures 212 through 2-15, respectively.

\section{$2.3 \quad$ NWCF Stack}

Table 2-3 presents the radioactive emissions from the NWCF VOG system. The radionuclides reported are those that have been routinely analyzed for in the ventilation stack emissions. Figure 2-16 depicts the total monthly activity.

\section{$2.4 \quad$ RAL Stack}

Table 2-4 presents the radioactive emissions from the RAI VOG system. The radionuclides reported are those that have been identified in the ventilation stack emissions. Figure 2-17 depicts the total monthly activity.

\subsection{Coal Fired Steam Generating Facility (CFSGF)}

The CFSGF stack is monitored continuously for sulfur dioxide $\left(\mathrm{SO}_{2}\right)$, nitrogen oxide $\left(\mathrm{NO}_{x}\right)$, and opacity. Carbon monoxide $(\mathrm{CO})$ is calculated by using AP-42 emission factors and fuel consumption rates. Emission limits for the stack are set by the Environmental Protection Agency (EPA) and the State of Idaho. Table 2-5 lists the releases per month for the CFSGF. The facility must provide a minimum removal efficiency of 708 for $\mathrm{SO}_{2}$ calculated as an average over a 30 day period. $\mathrm{SO}_{2}$ emissions shall not exceed an average of 0.6 pounds per MM/Btu of fuel input averaged over a 24 hour period. $\mathrm{NO}_{x}$ emissions shall not exceed an average of 0.5 pounds per MM/Btu of fuel input averaged over a 24 hour period when the steam load is equal to or greater than 35,000 pounds per hour. $\mathrm{NO}_{\mathbf{x}}$ emissions shall not exceed 0.7 pounds per MM/Btu of fuel input averaged over a 24 hour period when the steam load is less than 35,000 pounds per hour. Carbon monoxide shall not exceed $148.5 \mathrm{lbs} / \mathrm{hr}$ or $650.4 \mathrm{tons} / \mathrm{yr}$. Opacity limit for the CFSGF is $20 \%$. 
Table 2-2

AIRBORNE RELEASES FROM ICPP FAST STACK FY-1995

(curies)

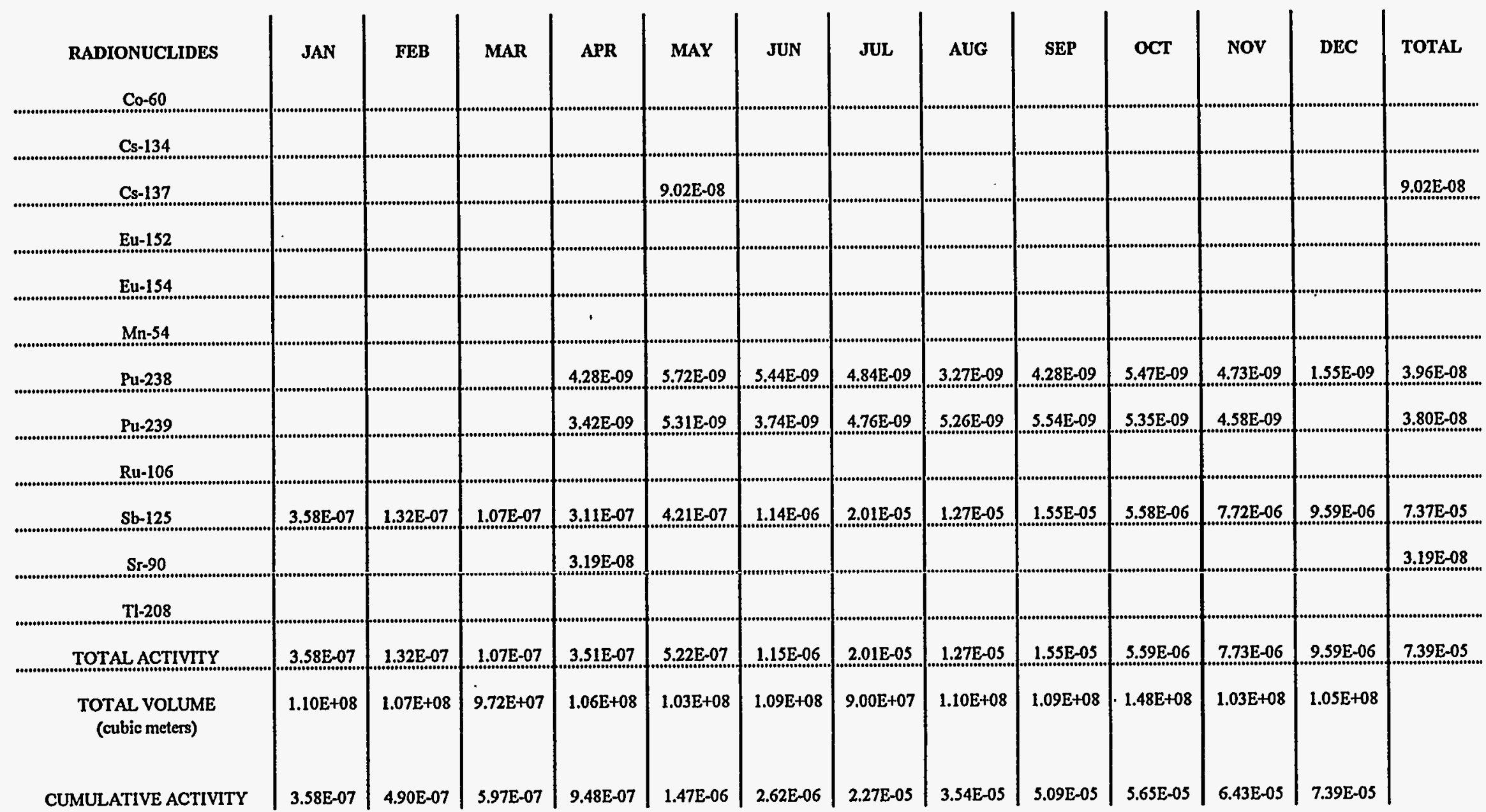

BLANKS FOR Sr-90 AND PU REPRESENT BELOW DETECTION AND REMAINING BLANKS REPRESENT NOT DETECTED IN THE GAMMA SCAN 
Figure 2-11

FAST STACK EFFLUENT

Total Activity (curies)

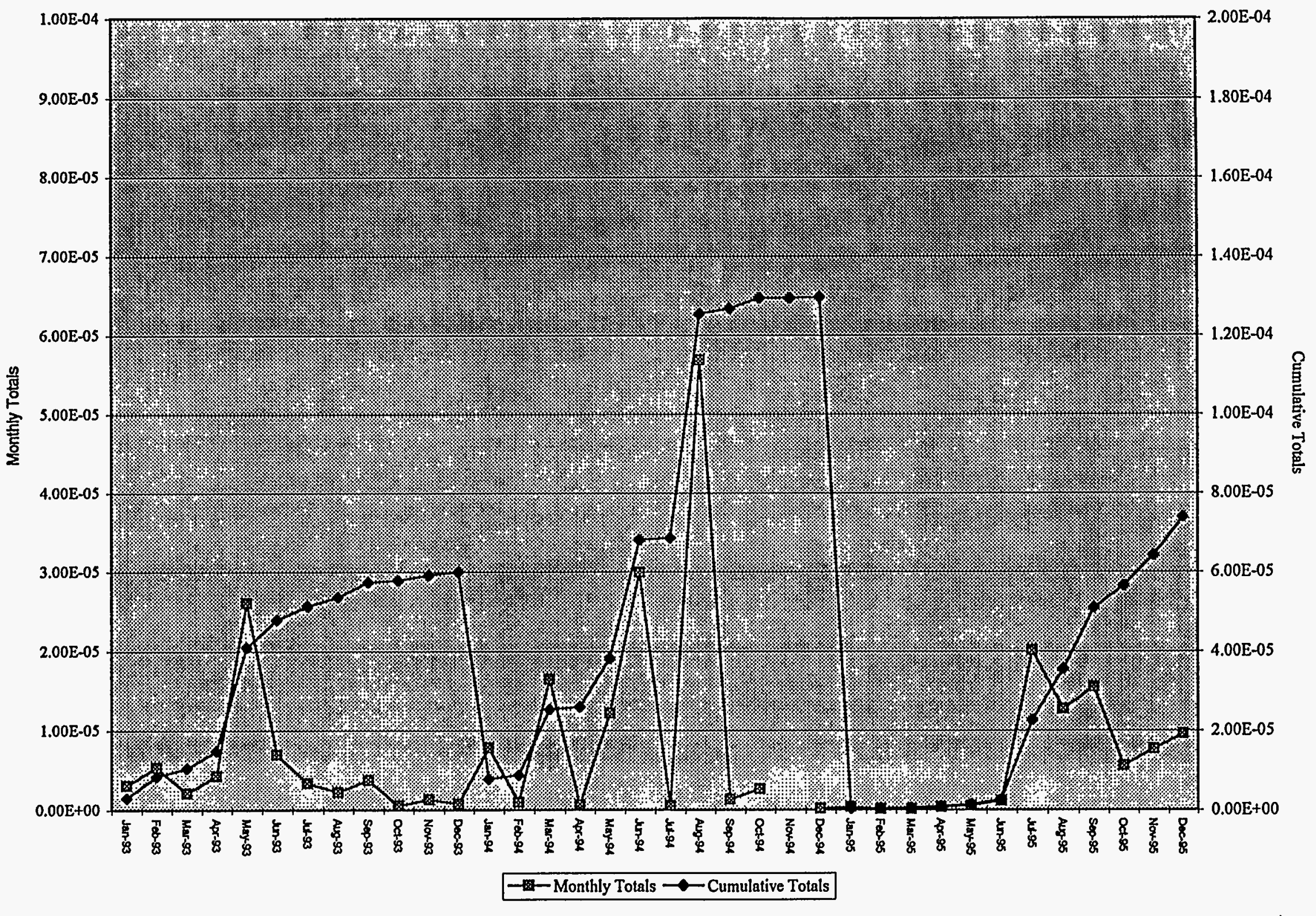




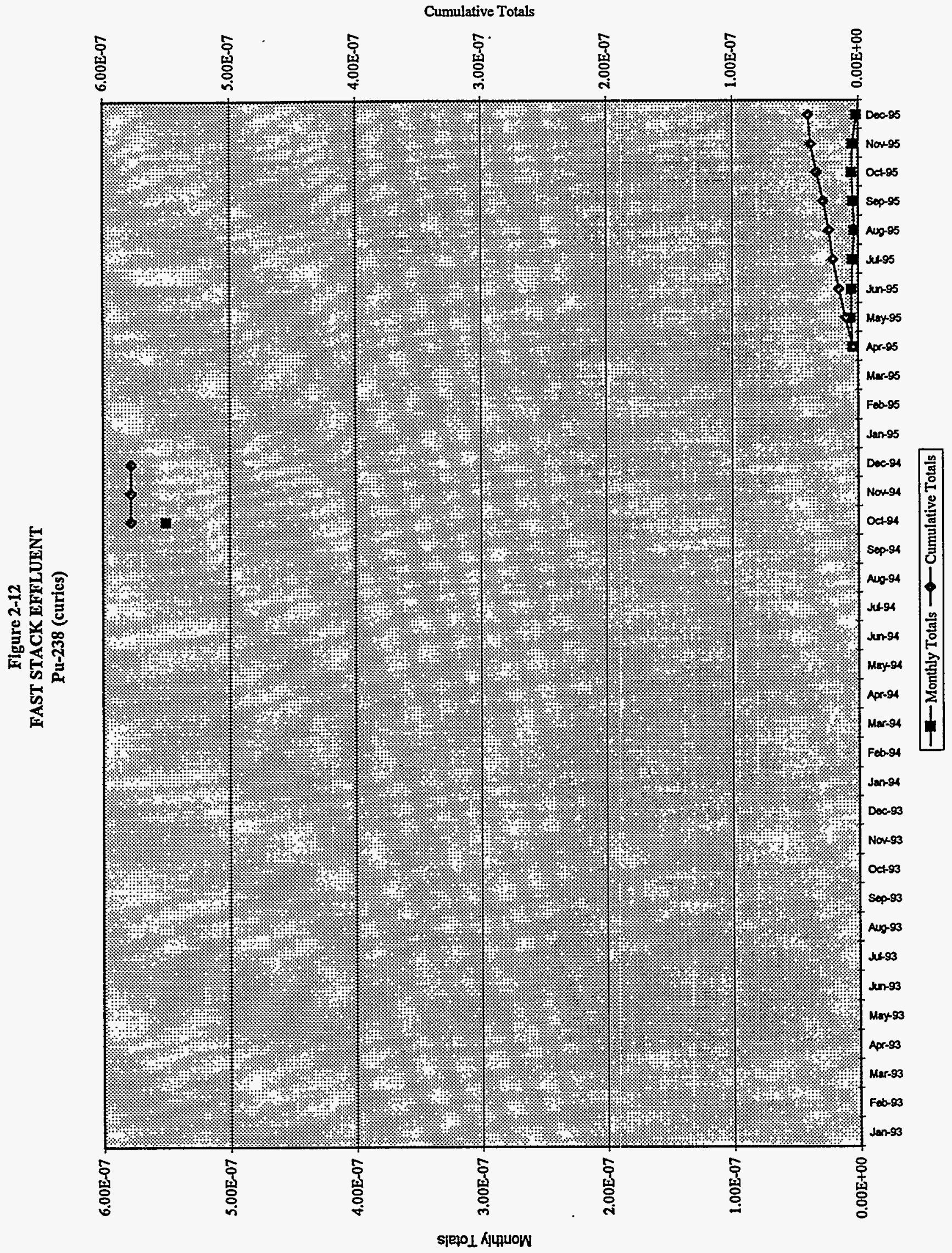




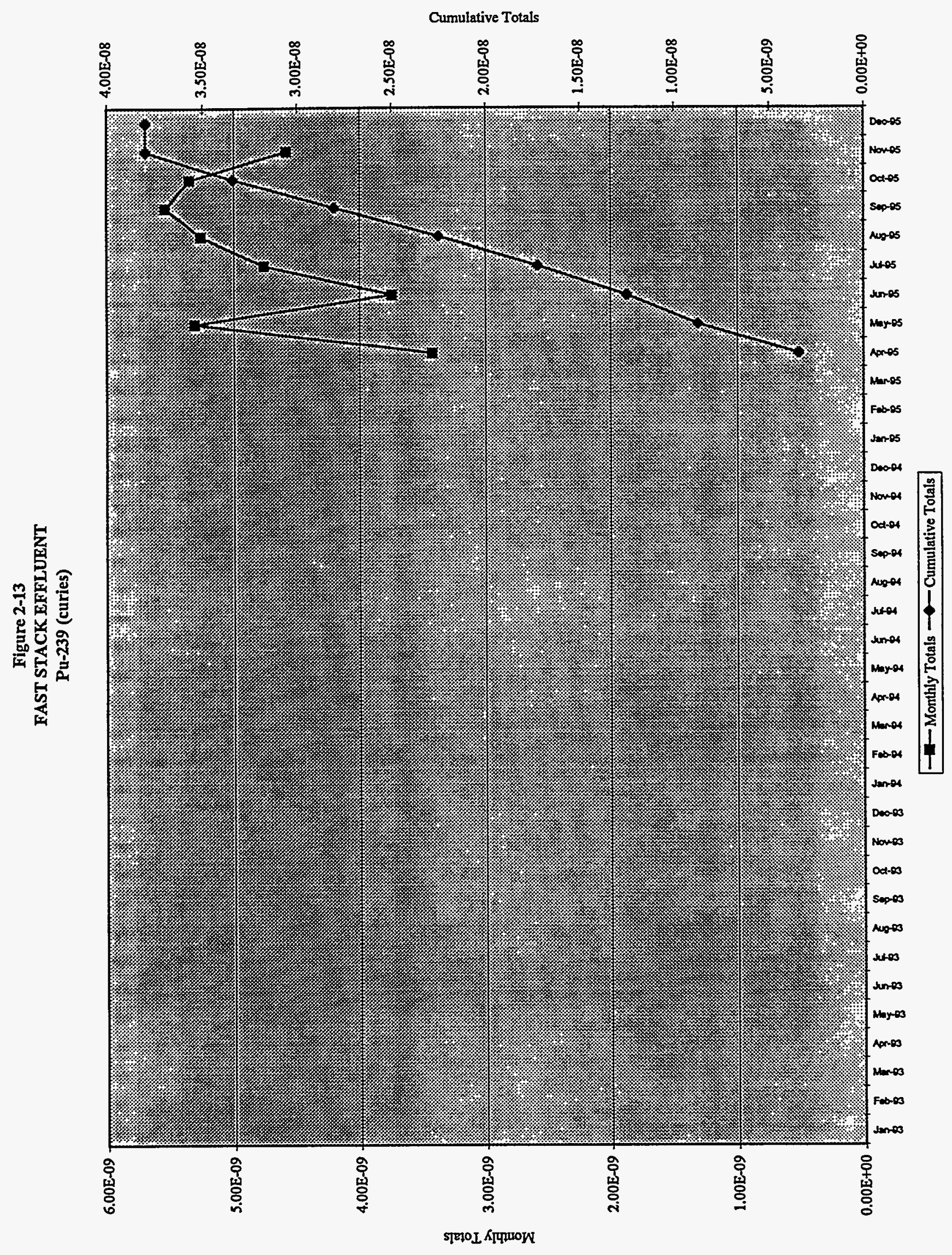


Figure 2-14

FAST STACK EFFLUENT

Sb-125 (curies)

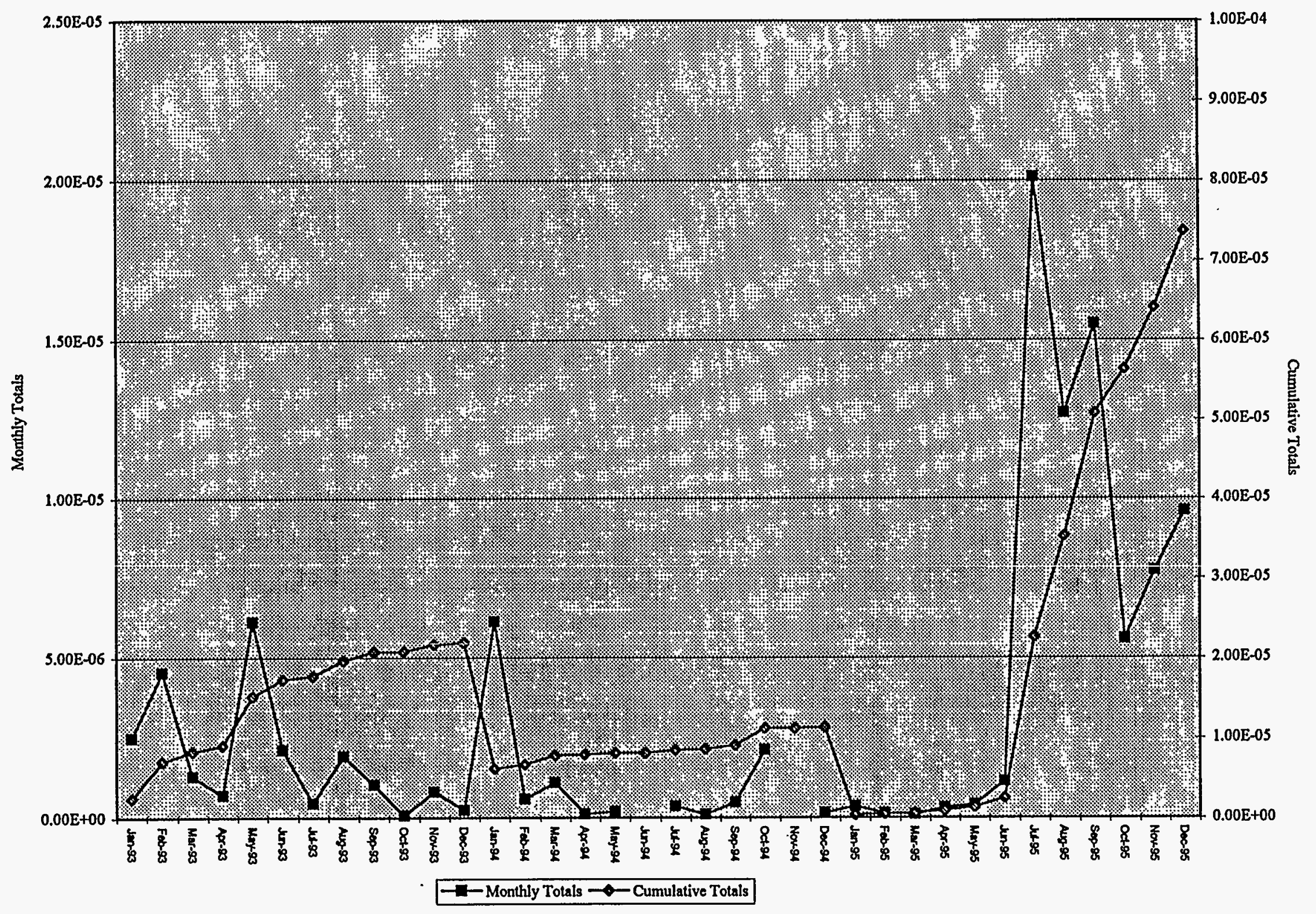


Figure 2-15

FAST STACK EFFLUENT

Cs-137 (curies)

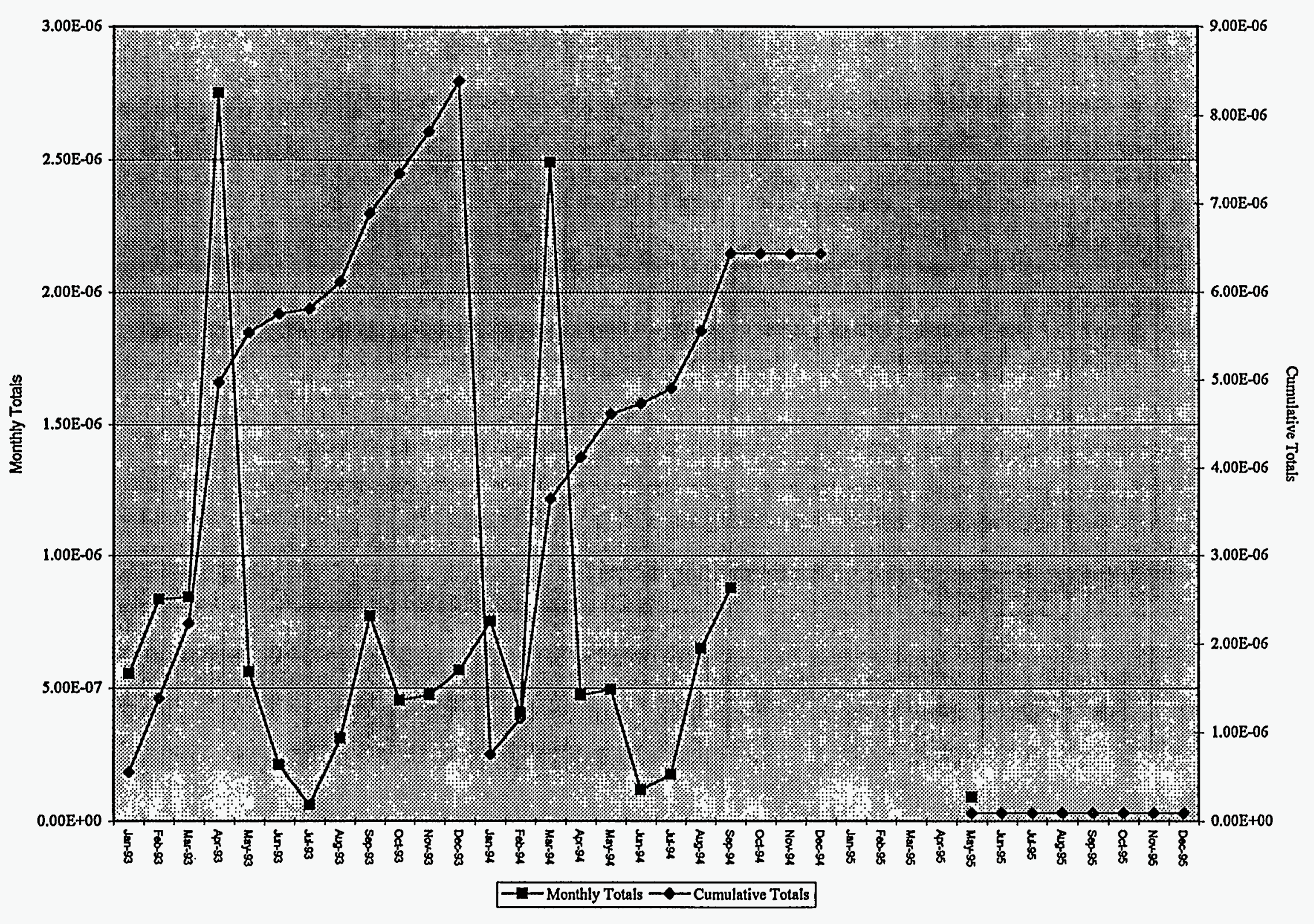


Table 2-3

AIRBORNE RELEASES FROM ICPP NWCF CY-1995

(curies)

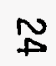

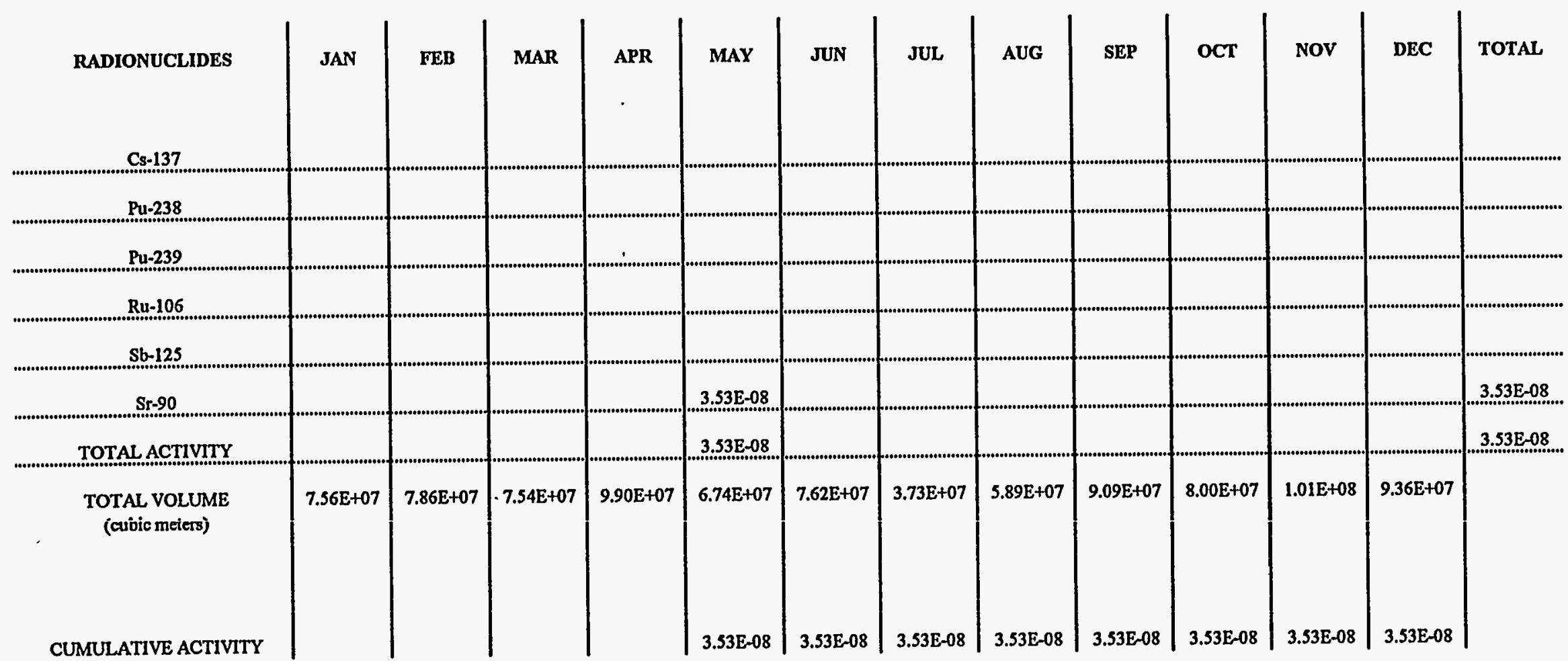

BLANKS REPRESENT BELOW DETECTION LIMITS 
Figure 2-16

NWCF STACK EFFLUENT

Total Activity (curies)

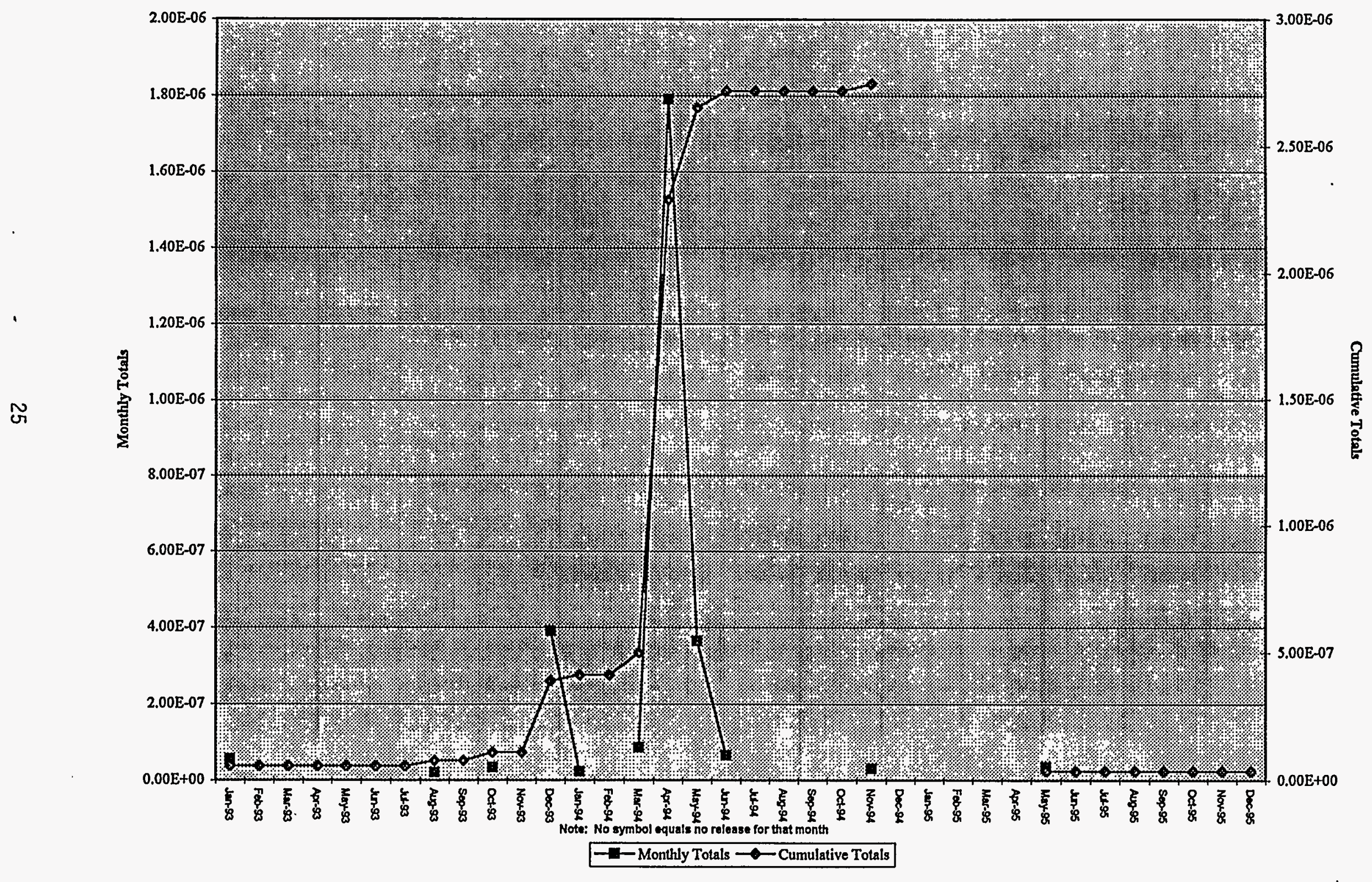




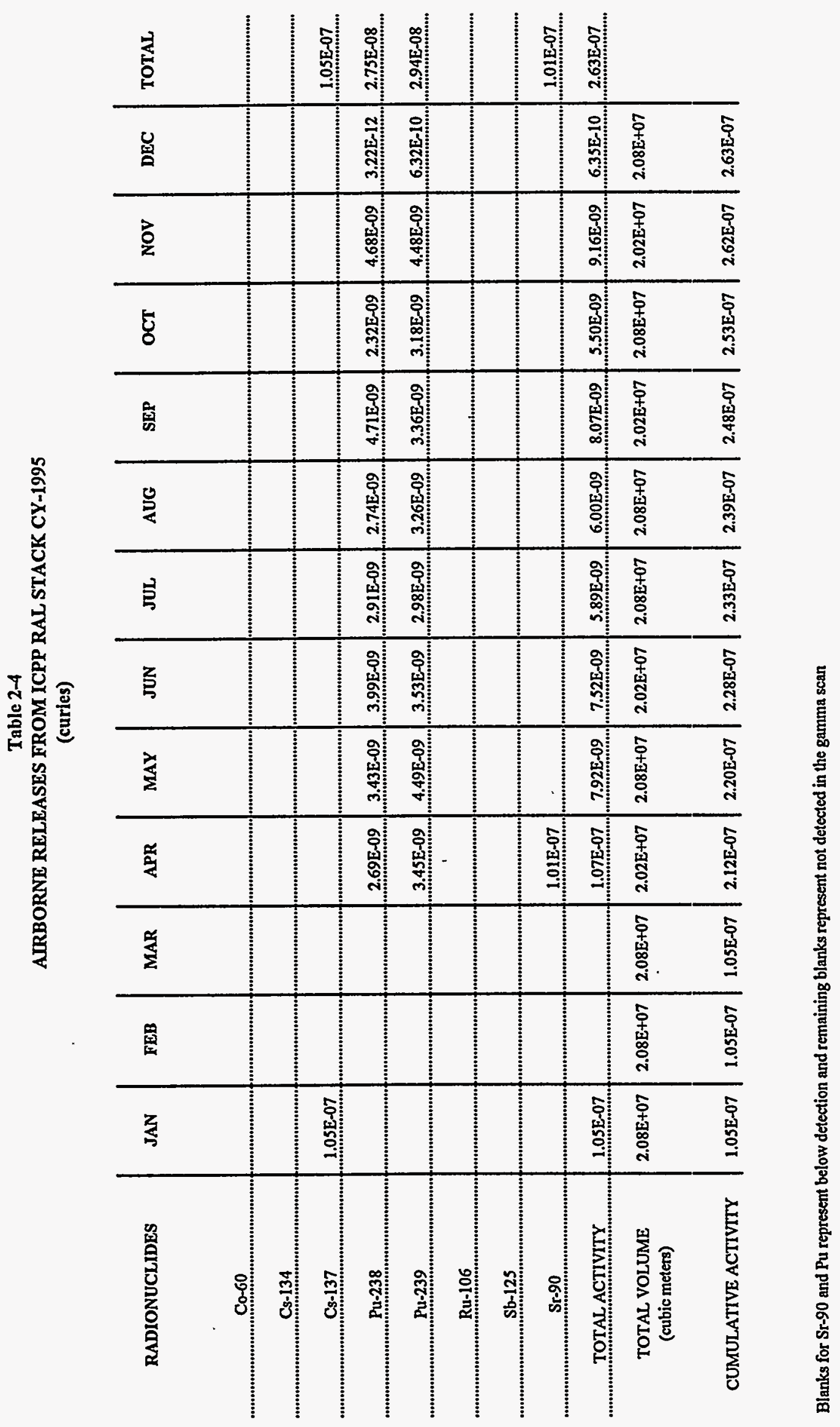


Figure 2-17

RAL STACK EFFLUENT

Total Activity (curies)

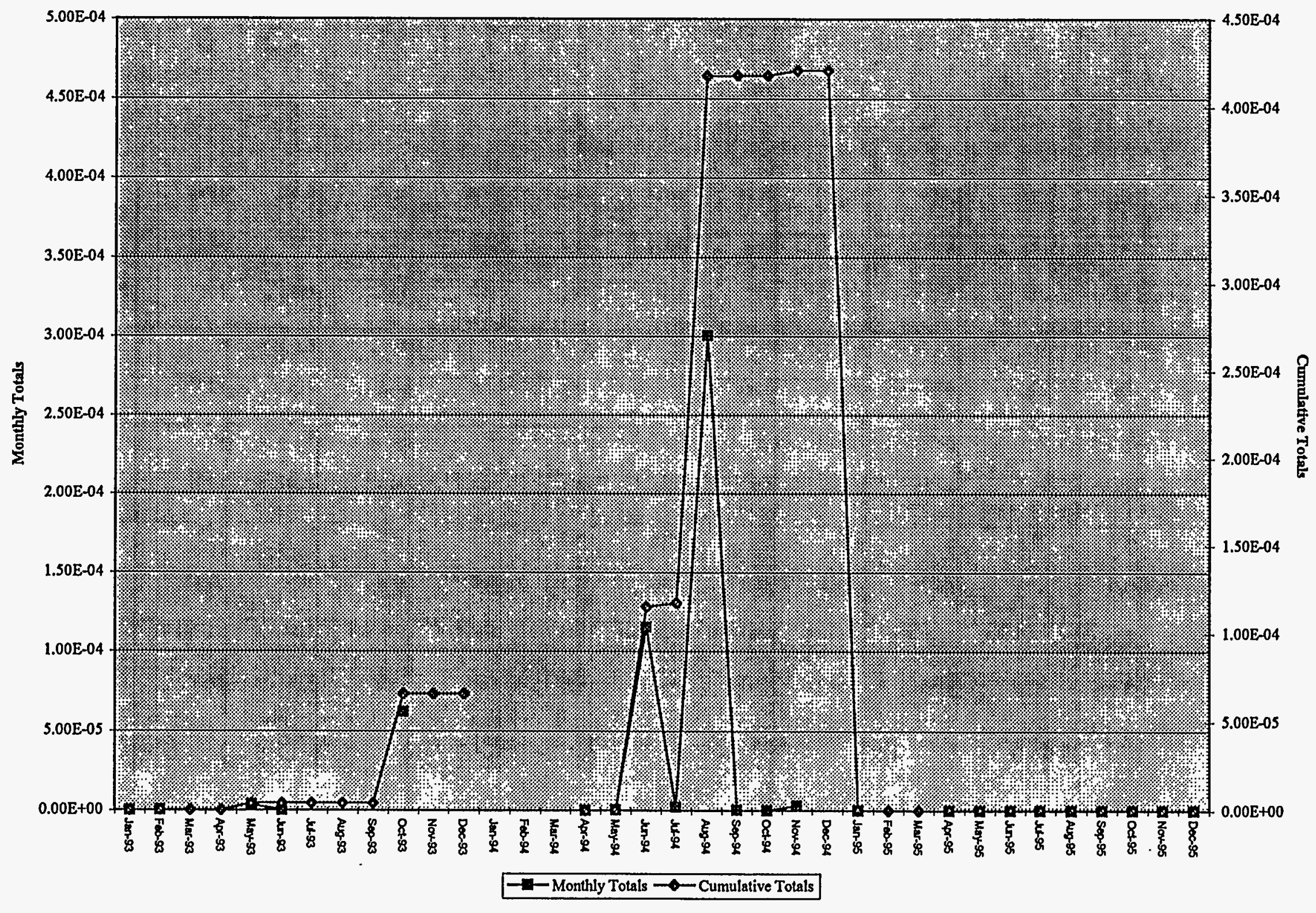


COAL FIRED STEAM GENERATOR FACUITY

\begin{tabular}{|c|c|c|c|c|c|c|c|c|c|c|c|c|c|}
\hline & JAN & FEB & MAR & APR & MAY & JUN & JUL & AUG & SEP & OCT & Nov & DEC & $\begin{array}{c}\text { EMISSION } \\
\text { LIMITATIONS }\end{array}$ \\
\hline COAL BURNED (TONS) & 1448 & 1370 & 1479 & 1298 & 1097 & 686 & 742 & 95 & of & 701 & 1332 & 1513 & N/A \\
\hline $\begin{array}{l}\text { CUMULATIVE COAL } \\
\text { BURNED (TONS) }\end{array}$ & 1448 & 2818 & 4297 & 5595 & 6692 & 7378 & 8120 & 8215 & 8215 & 8916 & 10248 & 11761 & N/A \\
\hline MM/Btu/HBurned & 0.012695 & 0.012695 & 0.012695 & 0.012695 & 0.012695 & 0.012668 & 0.012668 & 0.012668 & 0.000000 & 0.012668 & 0.012668 & 0.012668 & $\mathrm{~N} / \mathrm{A}$ \\
\hline$\%$ Sulfur & 0.43 & 0.43 & 0.43 & 0.43 & 0.43 & 0.37 & 0.37 & 0.37 & of & 0.37 & 0.37 & 0.37 & N/A \\
\hline \#NOx/MM/Btu & 0.37 & 0.42 & 0.38 & 0.41 & 0.51 & 0.51 & 0.6 & 0.65 & 0 & 0.43 & 0.45 & 0.4 & SEE FOOTNOTE \\
\hline \#SO2/MM/Btu & 0.03 & 0.03 & 0.06 & 0.04 & 0.09 & 0.08 & 0.1 & 0.11 & 0 & 0.04 & 0.09 & 0.09 & 0.6 \\
\hline $\begin{array}{c}\text { Permit Steam Flow Range A or } \\
\text { B }\end{array}$ & B & A & B & A & A & A & A & A. & 의 & A & A & $\underline{A}$ & SEE FOOTNOTE \\
\hline$\%$ SO2 Removed & 95 & 95.2 & 91.5 & 93.1 & 81 & 84 & 83.7 & 81.5 & 0 & 93.2 & 86.7 & 86.4 & 70\% OR GREATER \\
\hline$\%$ Opacity & 5 & 3 & & 1 & 1 & d & . & 1 & of & 2 & 3 & 3 & \\
\hline "Carbon Monixide (CO) lbs/lar & 33.3 & 34.94 & 33.1 & 25.8 & 20.8 & 15.6 & 14.8 & 14.8 & of & 22.8 & 24.7 & 30.4 & 148.5 \\
\hline Carbon Monixlde (CO) tons & 11.67 & 11.74 & 12.33 & 9.32 & 7.75 & 5.08 & 5.49 & 0.66 & 0 & 4.62 & 8.9 & 11.3 & \\
\hline $\begin{array}{l}\text { Carbon Monixlde (CO) TONS } \\
\text { CUMULATIVE }\end{array}$ & 11.67 & 23.41 & 35.74 & 45.06 & 52.81 & 57.89 & 63.38 & 64.04 & 64.04 & 68.66 & 77.56 & 88.86 & 650.4 \\
\hline
\end{tabular}

Opacity $=20 \%$

Coal Burned (tons) $=$ N/A

mm BTU/burned = NA

$\%$ Sulfur $=$ N/A

Nitrogen oxide (lbs. NOx/mmBTU) emissions shall not exceed an average of 0.5 pounds per million BTU's (Range B) for steam flow greater or equal to $35000 \mathrm{lbs} / \mathrm{hr}$.

Nitrogen oxide (lbs. NOx/mmBTU) emissions shall not exceed an average of 0.7 pounds per million BTU's (Range A) for steam flow less than $35000 \mathrm{lbs} / \mathrm{hr}$.

Sulfur dioxide (Ibs. SO2/mmBTU) emissions shall not exceed an sverage of 0.6 pounds per million BTU of fuel input, averaged over a 24 hour period.

$\%$ SO2 removal $=70 \%$ or greater and shall be calculated as an average over $a 30$ day period.

Steam now $=$ N/A (Range $B=$ steam load equal to or greater than 35000 pounds per hour and Range $A=$ steam load less than 35000 pounds per hour)

Carbon monoxide $(\mathrm{CO})$ emissions for the boilers shall not exceed an average of $148.5 \mathrm{lbs} / \mathrm{hr}$ averaged over a 30 day period 


\section{LIQUID MONITORING}

\section{INTRODUCTION}

Liquid monitoring discussed in this report includes: 1) Service Waste system; 2) Percolation Ponds $1 \& 2$ ) Sewage Treatment Plant; and 4) Production and Potable Water Wells. Quality Assurance objectives for measurement data and laboratory performance are listed in both the Quality Assurance Project Plan for the Analysis of Environmental Samples by the LITCO Analytical Chemistry Section and the Special Technologies Quality Assurance Project Plans for Work subject to EPA QAMS-005/80.

\section{LIQUID RELEASES TO THE ENVIRONMENT}

\subsection{Service Waste System}

Iiquid waste streams are generated from all areas of the ICPP. The waste streams vary in volume. Waste streams are disposed of through the service Waste system. The Liquid Effluent Treatment and Disposal (LET\&D) Facility began operation on January $1,1993$.

Wastewater Iand Application Permit (WLAP) IA-000130 for the Idaho Chemical Processing plant (ICPP) percolation ponds was effective september 20, 1995. The permit authorizes construction, installation, modification or operation of a WIAP treatment system in conformance with requirements, limitations and conditions required in the permit.

Isotopic radionuclide and inorganic chemical release data for the service Waste system for each month and year totals are presented in Table 3-1 and 3-2. Table 3-3 lists the monthly DCG release ratios respectively for individual radionuclides. DCGs are not release limits, but rather are screening values for considering Best Available Technology (BAT) for discharges and dose estimates.

The radionuclides reported are those that have been found in the past. Listed radionuclides that do not have values shown were not observed during the reporting month or were below detection limits. Figure 3-1 depicts the total monthly activity released to the active percolation Pond at ICPP.

Figure 3-2 depicts plutonium and figures 3-3 through 3-5 depicts uranium234, uranium-235, and uranium-238 found in the service waste stream. Figures 3-6 and 3-7 present trend information for select radionuclides in the Service Waste.

The ratio is calculated by dividing the detected radionuclide concentration by the established limit. Governmental regulations state that a corrected total ratio of 1.0 equals allowable radionuclide concentrations. The ICPP did not approach the total allowable release at any time during 1995.' The ICPP did not exceed a ratio of 1.0 during any month in 1995 . 


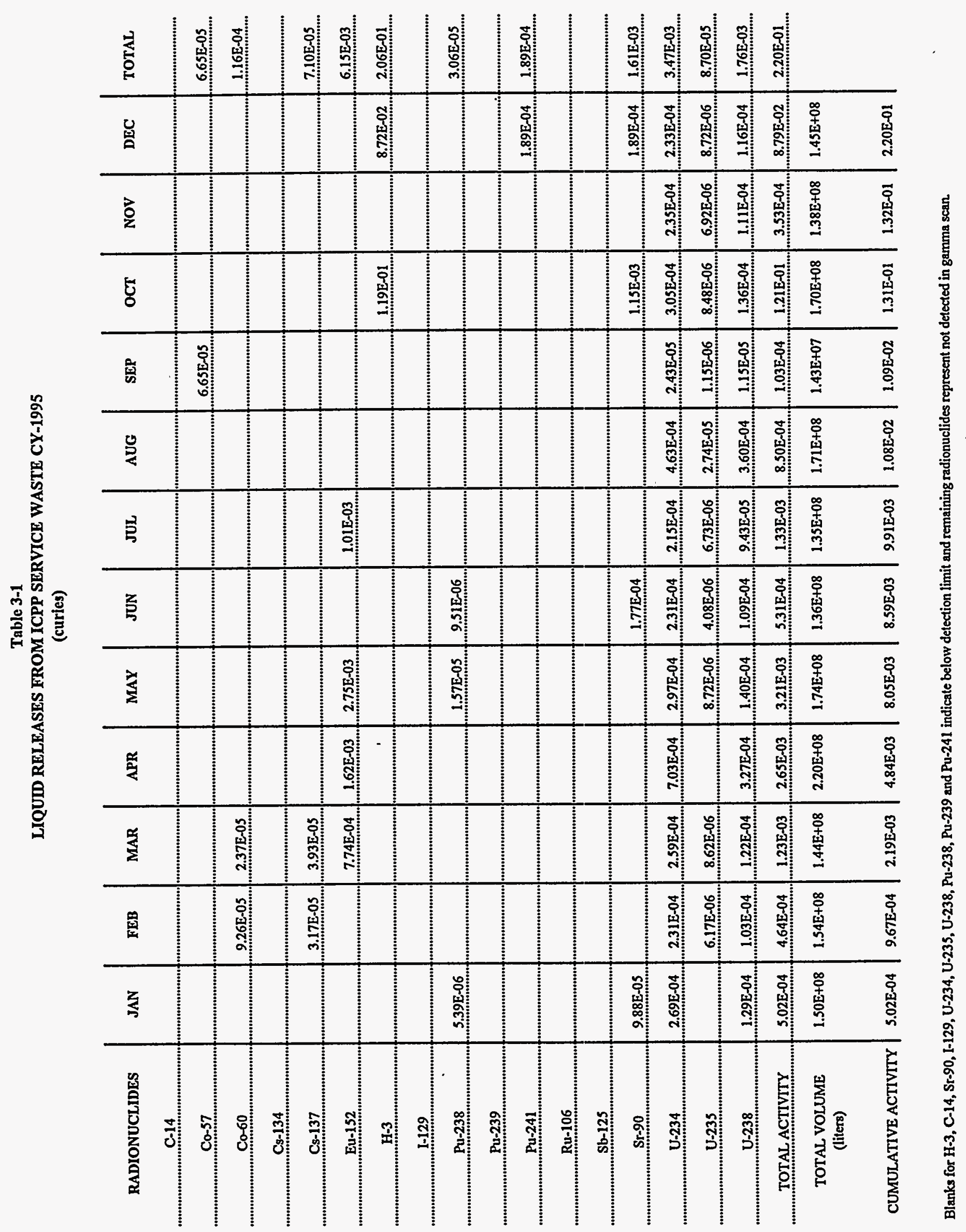


Table 3-2

ICPP SERVICE WASTE CY-1995

(mg/L)

\begin{tabular}{|c|c|c|c|c|c|c|c|c|c|c|c|c|c|}
\hline SUBSTANCE & JAN. & FEB. & MAR. & APR. & MAY & JUN. & JUL. & AUG. & SEP. & OCT. & Nov. & DEC. & *Levels \\
\hline Aluminum (Al) & & & & & $1.85 \mathrm{E}-01$ & & & & & & & & 0.05 to 0.2 \\
\hline Arsenic (As) & & & & & $2.10 \mathrm{E}-03$ & & & & & & & & S.00E-02 \\
\hline Barium (Ba) & $9.42 \mathrm{E}-02$ & $1.80 \mathrm{E}-01$ & $8.32 \mathrm{E}-02$ & $9.82 \mathrm{E}-02$ & $8.81 E-02$ & $1.09 \mathrm{E}-01$ & $7.40 \mathrm{E}-02$ & $7.59 \mathrm{E}-02$ & $6.65 \mathrm{E}-02$ & $1.30 \mathrm{E}-01$ & $1.04 \mathrm{E}-02$ & $9.56 \mathrm{E}-02$ & $1.00 \mathrm{E}+00$ \\
\hline Cadmium (Cd) & & & $1.18 \mathrm{E}-02$ & & & & & & . & & & & $1.00 \mathrm{E}-02$ \\
\hline Chloride Ion & $2.88 \mathrm{E}+02$ & $2.27 E+02$ & $2.96 \mathrm{E}+02$ & $2.68 \mathrm{E}+02$ & $2.82 \mathrm{E}+02$ & $2.33 \mathrm{E}+02$ & $2.62 \mathrm{E}+02$ & $2.53 E+02$ & $2.05 E+02$ & $2.78 \mathrm{E}+02$ & $2.97 \mathrm{E}+02$ & $2.94 E+02$ & $2.50 \mathrm{E}+02$ \\
\hline Chromium (Cr) & & $4.65 \mathrm{E}-03$ & & & $1.15 \mathrm{E}-02$ & $6.30 \mathrm{E}-03$ & $6.10 \mathrm{E}-03$ & $5.20 \mathrm{E}-03$ & $3.70 \mathrm{E}-03$ & $6.30 \mathrm{E}-02$ & $6.90 \mathrm{E}-03$ & $3.50 \mathrm{E}-03$ & $5.00 \mathrm{E}-02$ \\
\hline Copper (Cu) & & $7.45 \mathrm{E}-03$ & $3.26 \mathrm{E}-02$ & & $3.97 \mathrm{E}-02$ & & $2.10 \mathrm{E}-03$ & & & & $6.30 \mathrm{E}-03$ & $5.70 \mathrm{E}-03$ & $1.00 \mathrm{E}+00$ \\
\hline Fluoride lon & $2.14 \mathrm{E}-01$ & $2.00 \mathrm{E}-01$ & $2.03 \mathrm{E}-01$ & $2.42 \mathrm{E}-01$ & $2.19 \mathrm{E}-01$ & & & & & & & & $2.00 \mathrm{E}+00$ \\
\hline Iron & $3.71 \mathrm{E}-02$ & $7.34 \mathrm{E}-02$ & $4.64 \mathrm{E}-02$ & $2.67 \mathrm{E}-02$ & $5.78 \mathrm{E}-01$ & $2.63 \mathrm{E}-02$ & $1.20 \mathrm{E}-02$ & $1.02 \mathrm{E}-02$ & $1.16 \mathrm{E}-02$ & $5.70 \mathrm{E}-02$ & $3.44 \mathrm{E}-02$ & $2.29 \mathrm{E}-02$ & $3.00 \mathrm{E}-01$ \\
\hline Lead $(\mathrm{Pb})$ & & & & & & & & & & & & & $5.00 \mathrm{E}-02$ \\
\hline Manganese $(\mathrm{Mn})$ & & $1.20 \mathrm{E}-02$ & $5.90 \mathrm{E}-03$ & & $8.80 \mathrm{E}-03$ & & & $8.00 \mathrm{E}-04$ & & $4.86 \mathrm{E}-02$ & $1.60 \mathrm{E}-03$ & & $5.00 \mathrm{E}-02$ \\
\hline Mercury $(\mathrm{Hg})$ & & & & & & & & & & & & & $2.00 \mathrm{E}-03$ \\
\hline Nitrate (NO3-N) & $4.65 E+00$ & $4.78 \mathrm{E}+00$ & $4.93 \mathrm{E}+00$ & $4.88 \mathrm{E}+00$ & $4.35 \mathrm{E}+00$ & $5.24 \mathrm{E}+00$ & $5.06 \mathrm{E}+00$ & $4.72 E+00$ & $4.77 \mathrm{E}+00$ & $5.58 \mathrm{E}+00$ & $4.73 E+00$ & $5.11 E+00$ & $1.00 \mathrm{E}+01$ \\
\hline Nitrite Ion (NO2) & & & & & & & & & & & & & N/A \\
\hline Phosphate Ion & $2.80 \mathrm{E}-01$ & & & & & $2.69 \mathrm{E}-01$ & $2.54 \mathrm{E}-01$ & $1.27 \mathrm{E}-01$ & & & $4.72 \mathrm{E}-01$ & & N/A \\
\hline Selenium (Se) & & & & & & & & & & & $2.58 \mathrm{E}-03$ & & $1.00 \mathrm{E}-02$ \\
\hline Silver $(A B)$ & & $5.45 \mathrm{E}-03$ & & & & & & & & & & & $1.00 \mathrm{E}-01$ \\
\hline Sodium (Na) & $1.70 \mathrm{E}+02$ & $1.60 \mathrm{E}+02$ & $1.60 \mathrm{E}+02$ & $1.80 \mathrm{E}+02$ & $1.55 \mathrm{E}+02$ & $1.77 \mathrm{E}+02$ & $1.81 \mathrm{E}+02$ & $1.76 \mathrm{E}+02$ & $1.58 \mathrm{E}+02$ & $2.14 E+02$ & $1.66 \mathrm{E}+02$ & $1.96 \mathrm{E}+02$ & N/A \\
\hline Sulfate Ion & $2.32 \mathrm{E}+01$ & $2.76 \mathrm{E}+01$ & $2.76 \mathrm{E}+01$ & $2.71 \mathrm{E}+01$ & $2.68 \mathrm{E}+01$ & $2.70 \mathrm{E}+01$ & $2.80 \mathrm{E}+01$ & $2.68 \mathrm{E}+01$ & $2.65 \mathrm{E}+01$ & $2.81 E+01$ & $5.20 \mathrm{E}+01$ & $2.78 \mathrm{E}+01$ & $2.50 \mathrm{E}+02$ \\
\hline Total Disolved Solids (TDS) & $6.90 \mathrm{E}+02$ & $5.58 \mathrm{E}+02$ & $6.76 \mathrm{E}+02$ & $7.43 \mathrm{E}+02$ & $6.03 E+02$ & $6.79 \mathrm{E}+02$ & $6.19 \mathrm{E}+02$ & $5.98 \mathrm{E}+02$ & $6.29 \mathrm{E}+02$ & $8.97 E+02$ & $7.03 \mathrm{E}+02$ & $6.74 E+02$ & $5.00 \mathrm{E}+02$ \\
\hline Conductivity (uMhos) & 1,280 & 1,300 & 1,260 & 1,300 & 1,260 & & 1,172 & 1,158 & 1142 & 1,611 & 1,333 & 1,330 & N/A \\
\hline pH & 8.4 & 8.4 & 8.39 & 8.61 & 8.4 & 8.16 & 8.62 & 8.46 & 8.67 & 8.39 & 8.78 & 8.53 & $6.5-8.5$ \\
\hline TKN & & & & & & & & & & 328 & & & N/A \\
\hline
\end{tabular}

-Levels established from 40 CFR 141.11 and 143.2 
Table 3-3

DOE DCG RATIOS CY-1995

\begin{tabular}{|c|c|c|c|c|c|c|c|c|c|c|c|c|}
\hline RADIONUCLIDES & JAN & FEB & MAR & APR & MAY & $\mathrm{JN}$ & $\pi \Omega$ & AUG & SEP & OCT & Nov & DEC \\
\hline C-14 & & & & & & & & & & & & \\
\hline Co-57 & & & & & & & & & 4.65E -05 & & & \\
\hline Co-60 & & $1.20 \mathrm{E}-04$ & $3.29 \mathrm{E}-05$ & & & & & & & & & \\
\hline Cs-134 & & & & & & & & & & & & \\
\hline Cs-137 & & $6.86 \mathrm{E}-05$ & $9.10 \mathrm{E}-05$ & & & & & & & & & \\
\hline Eu-152 & & & $5.38 \mathrm{E}-04$ & $7.36 \mathrm{E}-04$ & $1.58 \mathrm{E}-03$ & & $7.48 \mathrm{E}-04$ & & & & & \\
\hline $\mathrm{H}-3$ & & & & & & & & & & & & 3.01E-04 \\
\hline I-129 & & & & & & & & & & & & \\
\hline Pu-238 & $8.98 \mathrm{E}-04$ & & & & $2.26 \mathrm{E}-03$ & $1.75 E-03$ & & & & & & \\
\hline Pu-239 & & & & & & & & & & & & \\
\hline Pu-241 & & & & & & & & & & & & $6.52 \mathrm{E}-04$ \\
\hline $\mathrm{Ru}-106$ & & & & & & & & & & & & \\
\hline$S b-125$ & & & & & & & & & & & & \\
\hline $\mathrm{Sr}-90$ & $6.59 \mathrm{E}-04$ & & & & & $\begin{array}{l}1.30 \mathrm{E}-03 \\
\end{array}$ & & & & $6.76 \mathrm{E}-03$ & & $1.30 \mathrm{E}-03$ \\
\hline U.234 & $3.59 \mathrm{E}-03$ & $3.00 \mathrm{E}-03$ & $3.60 \mathrm{E}-03$ & $6.39 \mathrm{E}-03$ & $3.41 E-03$ & $3.40 \mathrm{E}-03$ & $3.19 \mathrm{E}-03$ & $5.42 \mathrm{E}-03$ & $3.40 E-03$ & $3.59 \mathrm{E}-03$ & $3.41 \mathrm{E}-03$ & $3.21 \mathrm{E}-03$ \\
\hline U.235 & & $6.68 \mathrm{E}-05$ & $9.98 \mathrm{E}-05$ & & $8.35 \mathrm{E}-0 \mathrm{~s}$ & $5.00 \mathrm{E}-05$ & $8.31 E-05$ & 2.67E-04 & $1.34 \mathrm{E}-04$ & $8.31 \mathrm{E}-05$ & $8.36 \mathrm{E}-05$ & $1.00 \mathrm{E}-04$ \\
\hline U-238 & $1.43 \mathrm{E}-03$ & 1.111E-03 & 1.41E-03 & $2.48 \mathrm{E}-03$ & $1.34 \mathrm{E}-03$ & $1.34 \mathrm{E}-03$ & $1.16 \mathrm{E}-03$ & $3.51 \mathrm{E}-03$ & $1.34 \mathrm{E}-03$ & $1.33 \mathrm{E}-03$ & $1.34 \mathrm{E}-03$ & $1.33 \mathrm{E}-03$ \\
\hline
\end{tabular}




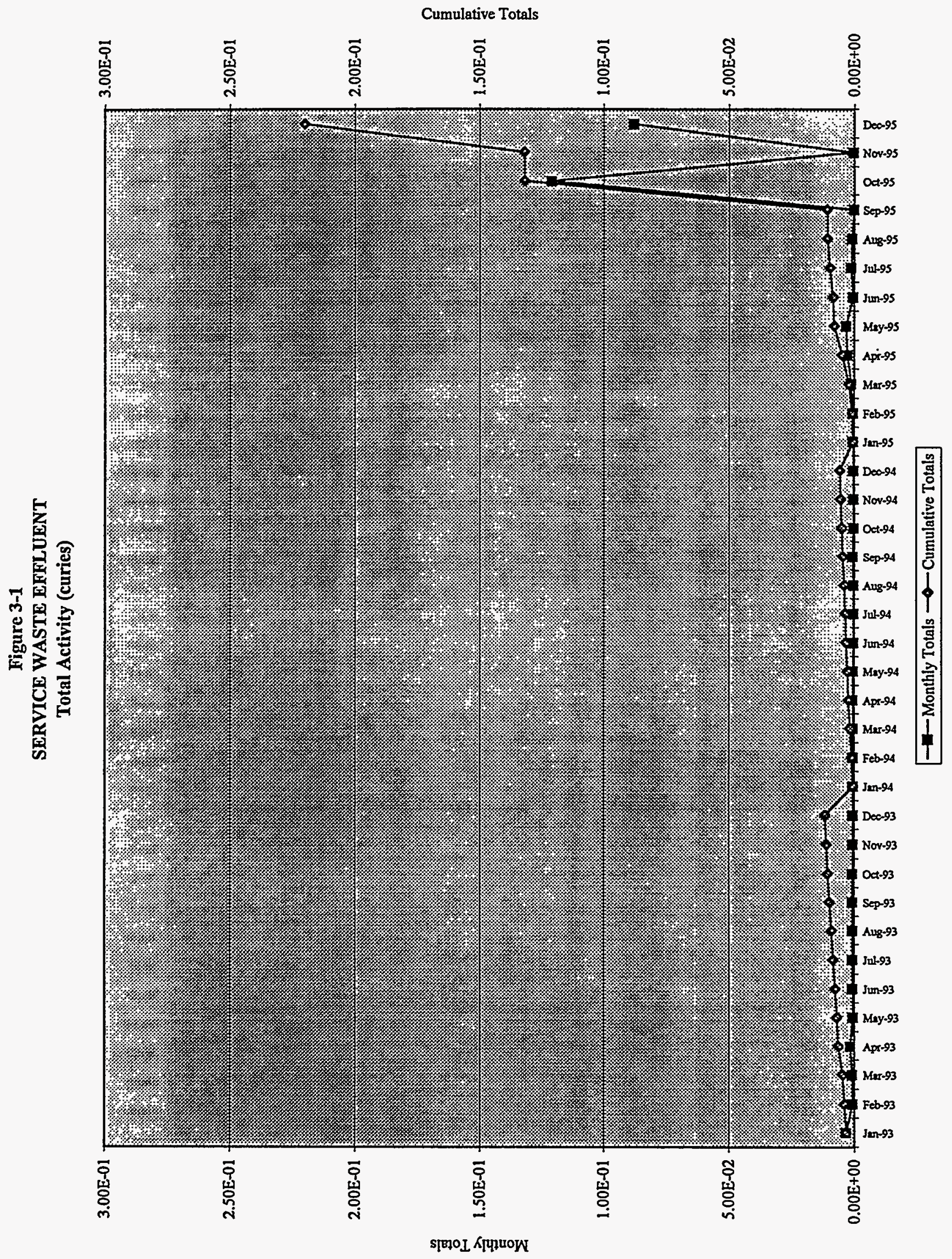




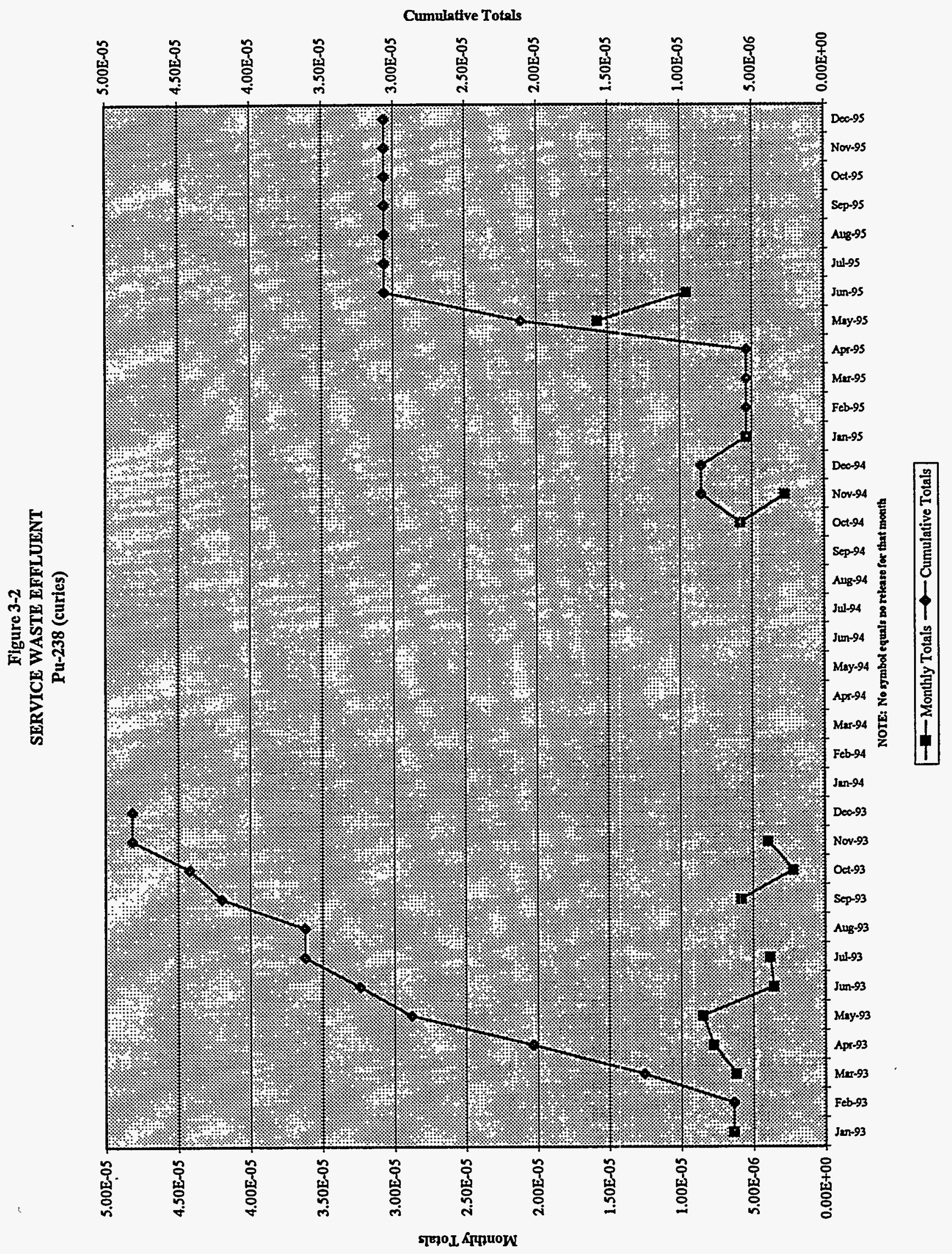


Figure 3-3

SERVICE WASTE EFFLUENT

U-234 (curies)



November, December 1993 and January 1994 are Uranlum totals 
Figure 3-4

SERVICE WASTE EFFLUENT

U-235 (curies)

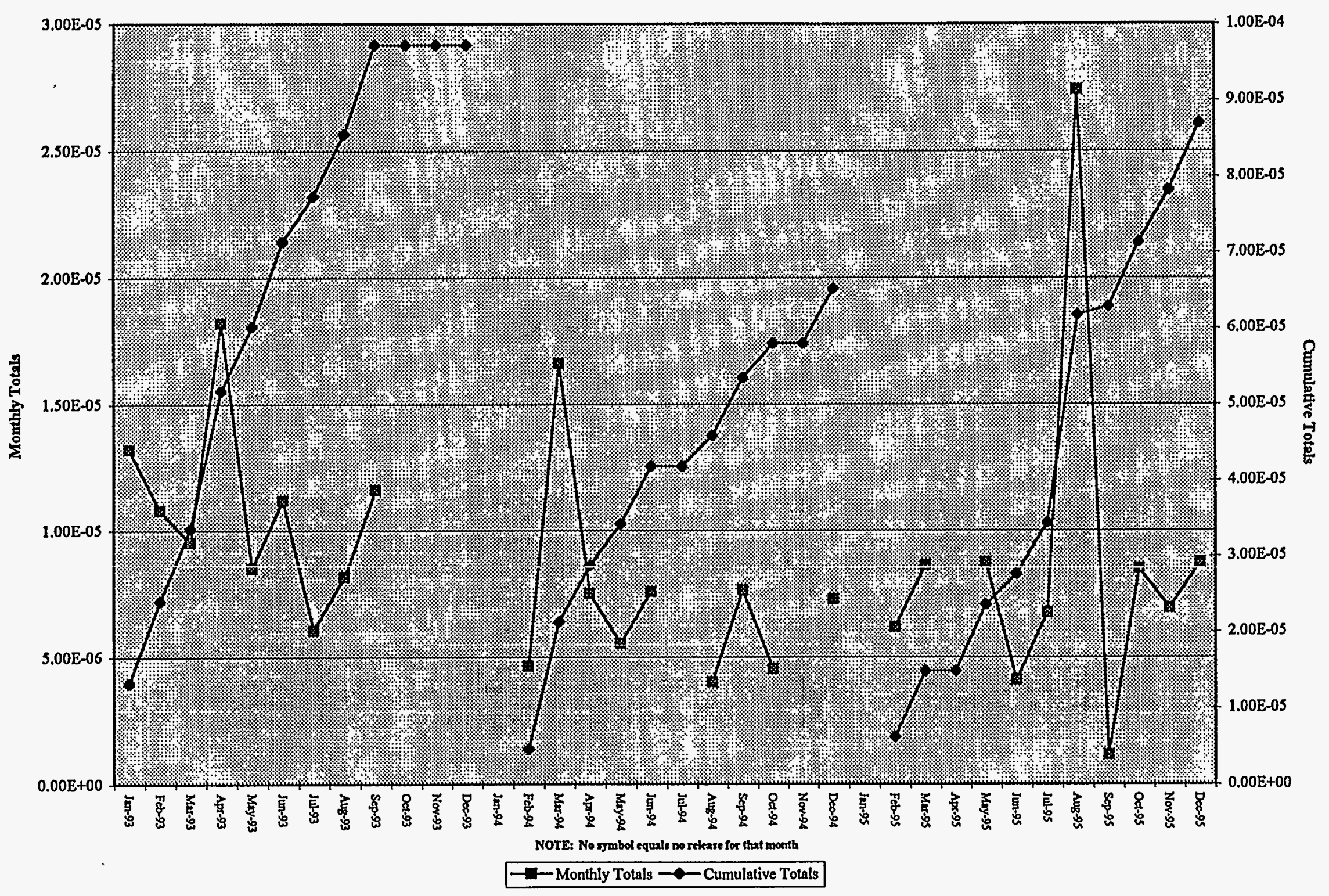

November, December 1993 and January 1994 is Included in U-234 as total Uranlum 
Figure 3-5

SERVICE WASTE EFFLUENT

U-238 (curies)

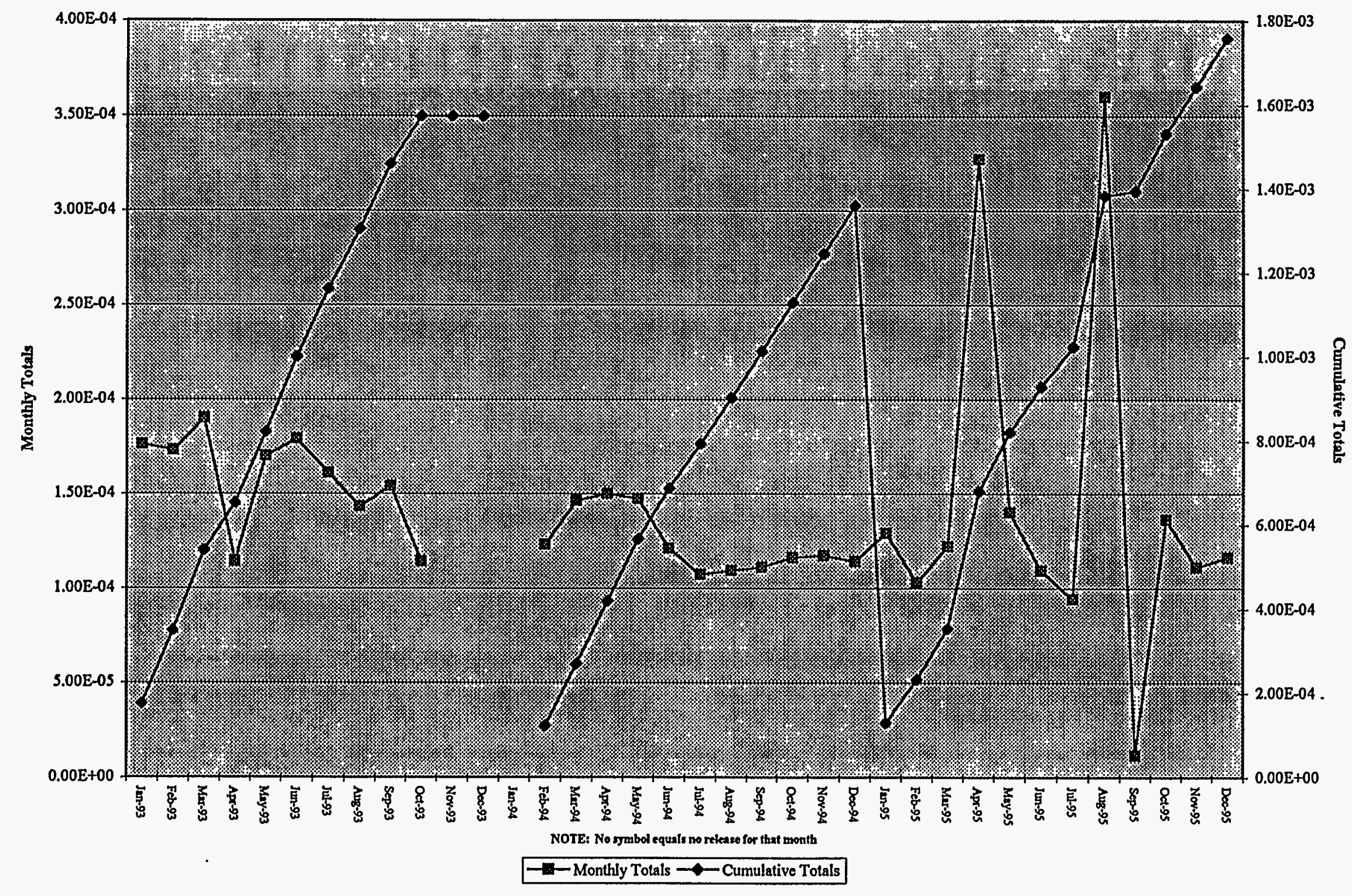

November, December 1993 and January 1994 is Included in U-234 as total Uranlum 


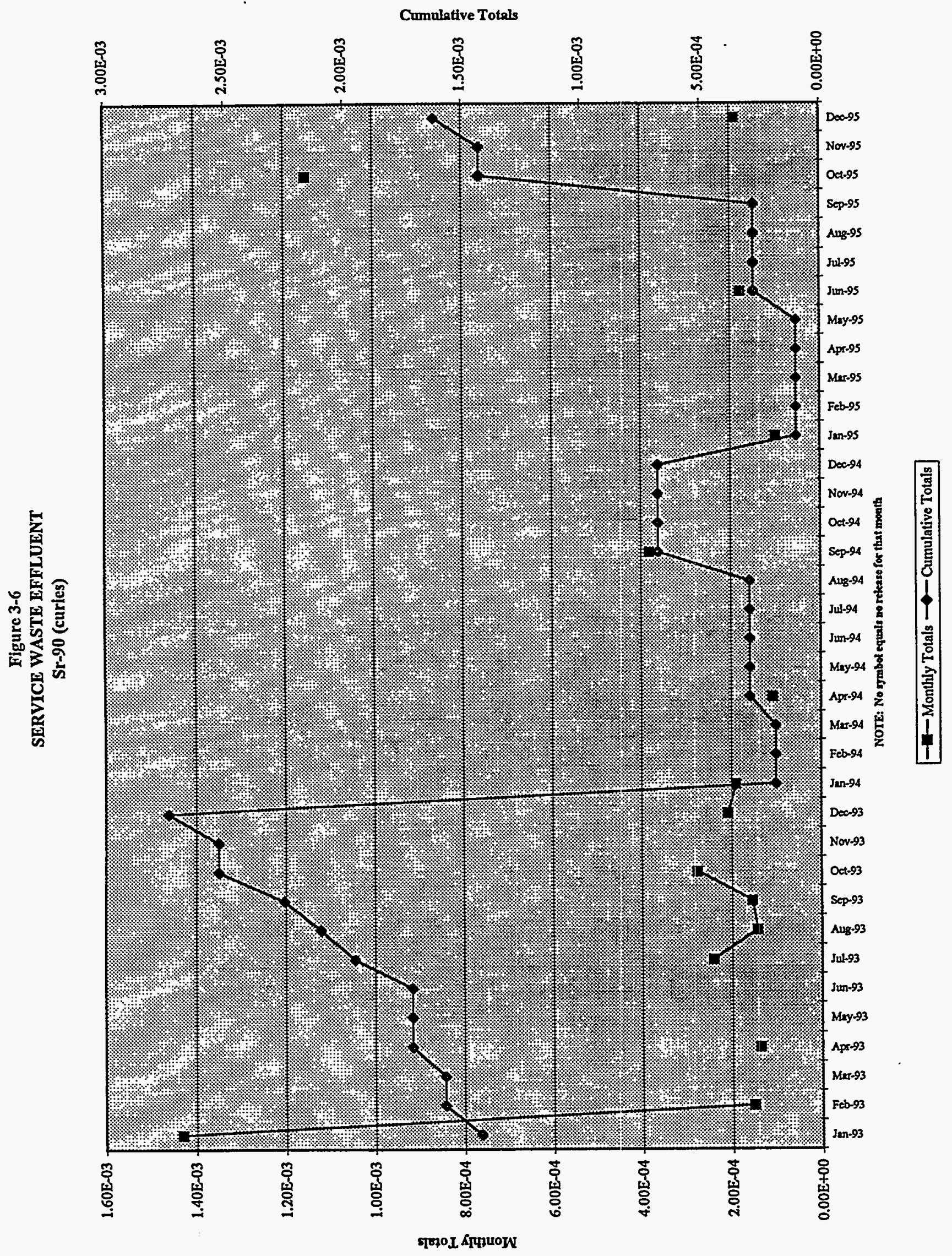




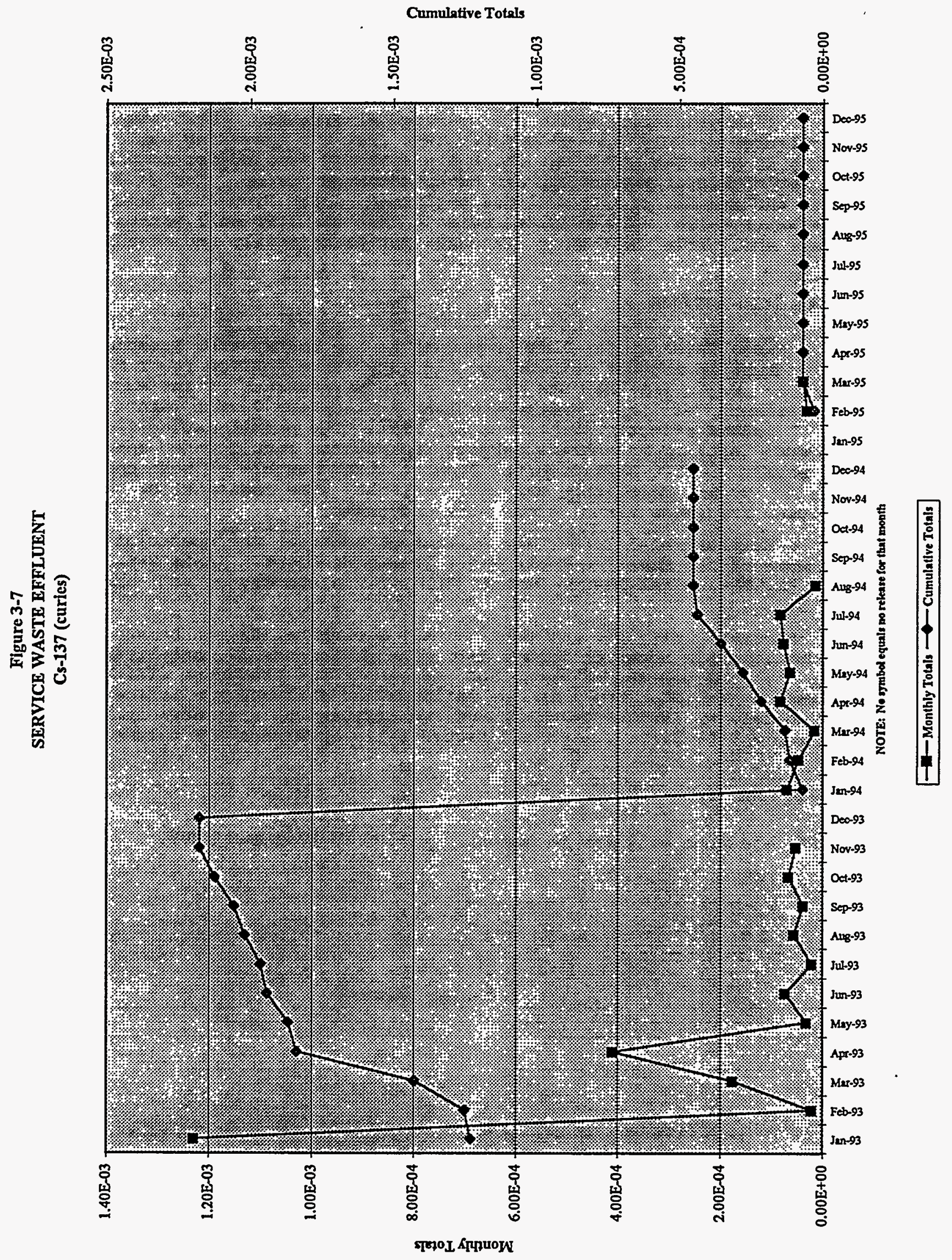


There are two production wells and one potable water well for influent at the ICPP. The production wells are operated alternately. Grab samples were collected monthly through october 1995 from the operating wells. Beginning in November, 1995 the wells are randomly sampled for compliance by the Environmental Monitoring and Water Resources Group. Tables 3-4 and 3-5 list the results of the analyses performed on the Production and Potable Water Wells. All results indicate that the ICPP well waters are below all applicable regulatory standards for trace metals and organics.

\subsection{Sewage Treatment Plant}

Domestic waste water at the ICPP is pumped to the Waste Water Treatment Facility which is located outside the securit. fence. IITCO Power Plant Services is responsible for the operation and maintenance of the Waste Water Treatment Facility. Wastewater Iand Application Permit (WLAP) IA000115-02 became effective september 17, 1995. The permit authorizes the wasterwater facility to operate subject to specific requirements specified in the permit. IITCO Environmental support takes monthly 24 hour composite samples for permit compliance and radionuclides. The radionuclide sample is analyzed for gross alpha, gross beta and gamma.

The IITCO Environmental Protection Department monitors the operation and performance of the domestic Waste Water Treatment Plant. Table 3-6 lists the monthly Biological Oxygen Demand (BOD), Dissolved oxygen (DO) and pH for 1995.

Monthly influent.(raw) and effluent (final) Biological oxygen Demand (BOD) concentrations are shown in Figure 3-8. The difference in concentrations between influent BOD and effluent BOD represents the treatment efficiency. Dissolved Oxygen (DO) levels in the influent and effluent are indicators of proper operation. Values for influent and effluent Do are shown in Figure 3-9. Figure 3-10 lists the $\mathrm{pH}$ and Figure 3-11 represents STP volume.

\subsection{ICPP Injection Well}

The ICPP injection well was permanently sealed in November 1989. 


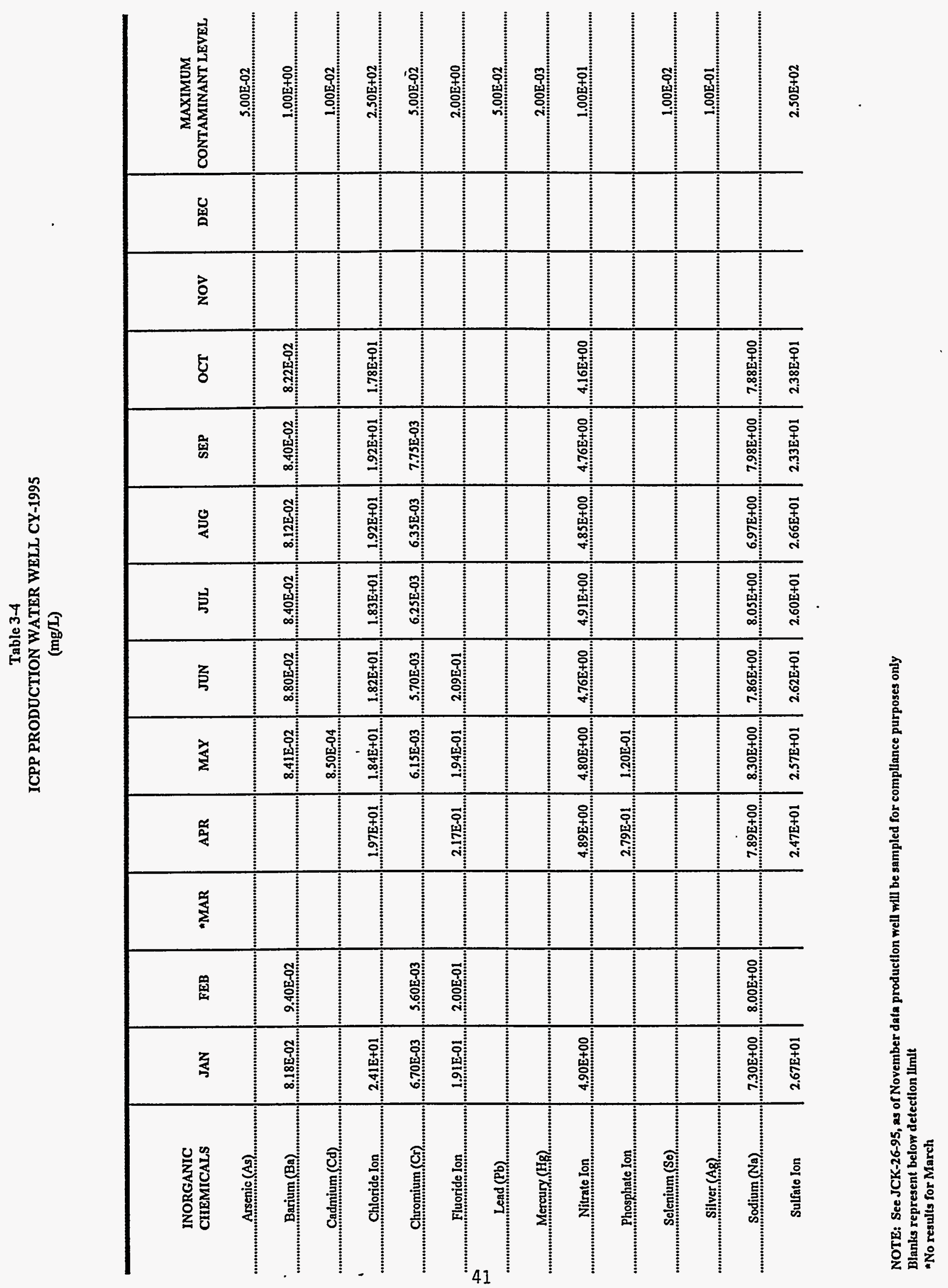


Table 3-5

ICPP POTABLE WATER WELL CY-1995

(in $\mathrm{mg} / \mathrm{L}$ )

\begin{tabular}{|c|c|c|c|c|c|c|c|c|c|c|c|c|c|}
\hline 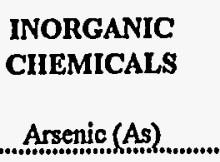 & JAN & FEB & "MAR & APR & MAY & $\begin{array}{c}\text { JUN } \\
2.00 E-03\end{array}$ & JUL & AUG & SEP & OCT & Nov & DEC & $\begin{array}{c}\text { MAXIMUM } \\
\text { CONTAMINANT LEVEL } \\
\end{array}$ \\
\hline Barium (Ba). & 8.75E-02 & & & & $8.96 \mathrm{E}-02$ & $8.70 \mathrm{E}-02$ & ...60E-02 & $. .70 \mathrm{E}-02$ & $. . .52 \mathrm{E}-02$ & $.8 .98 \mathrm{E}-02$ & & & $1.00 \mathrm{E}+00$ \\
\hline Cadmium $(\mathrm{Cd})$ & & & & & & & & & & & & & 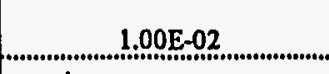 \\
\hline Chloride Ion. & $2.02 E+01$ & $1.88 E+01$ & & $1.83 E+01$ & $1.80 \mathrm{E}+01$ & $1.79 E+01$ & $1.82 E+01$ & $1.77 E+01$ & $1.93 E+01$ & $1.98 E+01$ & & & $.2 .50 \mathrm{E}+02$ \\
\hline Chromium $(\mathrm{Cr})$ & $5.80 \mathrm{E}-03$ & 5.05E-03 & & & $5.15 E-03$ & ....45E-03............ & $5.65 \mathrm{E}-03$ & $6.15 E-03 \ldots$ & $7.00 \mathrm{E}-03 \ldots$ & $6.40 \mathrm{E}-03 \ldots$ & & & $5.00 E-02$ \\
\hline Fluoride Ion & 1.90E-01 & 2.02E-01 & & 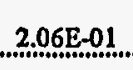 & ..14E-01. & $2.00 \mathrm{E}-01$ & & & & & & & $2.00 \mathrm{E}+00$ \\
\hline 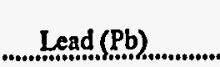 & & & & & & & & & & & & & 5.00E-02. \\
\hline 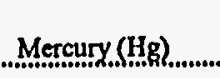 & & & & & & & & & & & & & $2.00 E-03$ \\
\hline Nitrate Ion & $4.818+00$ & $8.01 \mathrm{E}-01$ & & $4.83 E+00$ & $4.71 E+00$ & $4.86 \mathrm{~g}+00$ & $4.94 \mathrm{E}+00$ & $4.68 E+00$ & $4.98 \mathrm{E}+00$ & $4.86 \mathrm{E}+00$ & & & $1.00 E+01$ \\
\hline Phosphate lon & & & & .2.79E-01. & $1.20 E-01$ & & & & & & & & \\
\hline Selenium (Se) & & & & & & & & & & & & & $1.00 \mathrm{E}-02$. \\
\hline Silvet (Ag). & & & & & & & & & & ...33E-03. & & & 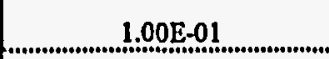 \\
\hline Sodium $(\mathrm{Na})$. & $6.80 \mathrm{E}+00$ & $1.00 \mathrm{E}+02$ & & $7.71 E+00$ & $8.50 \mathrm{E}+00$ & $7.78 \mathrm{E}+00$ & $7.75 \mathrm{E}+00$ & $7.25 \mathrm{E}+00$ & $8.20 E+00$ & $7.63 E+00$ & & & \\
\hline Sulfate Ion & $2.59 \mathrm{E}+01$ & $2.65 E+01$ & & $2.49 E+01$ & $2.55 \mathrm{E}+01$ & $2.67 \mathrm{E}+01$ & $2.70 \mathrm{E}+01$ & $2.56 \mathrm{E}+01$ & $2.33 \mathrm{E}+01$ & $2.47 E+01$ & & & $2.50 \mathrm{E}+02$ \\
\hline
\end{tabular}

SEE JCK-26-95, as of November data, potable well will be sampled for compllance purposes only

Blanks represent below detectlon Ilmit

•No potable water well Information for March 


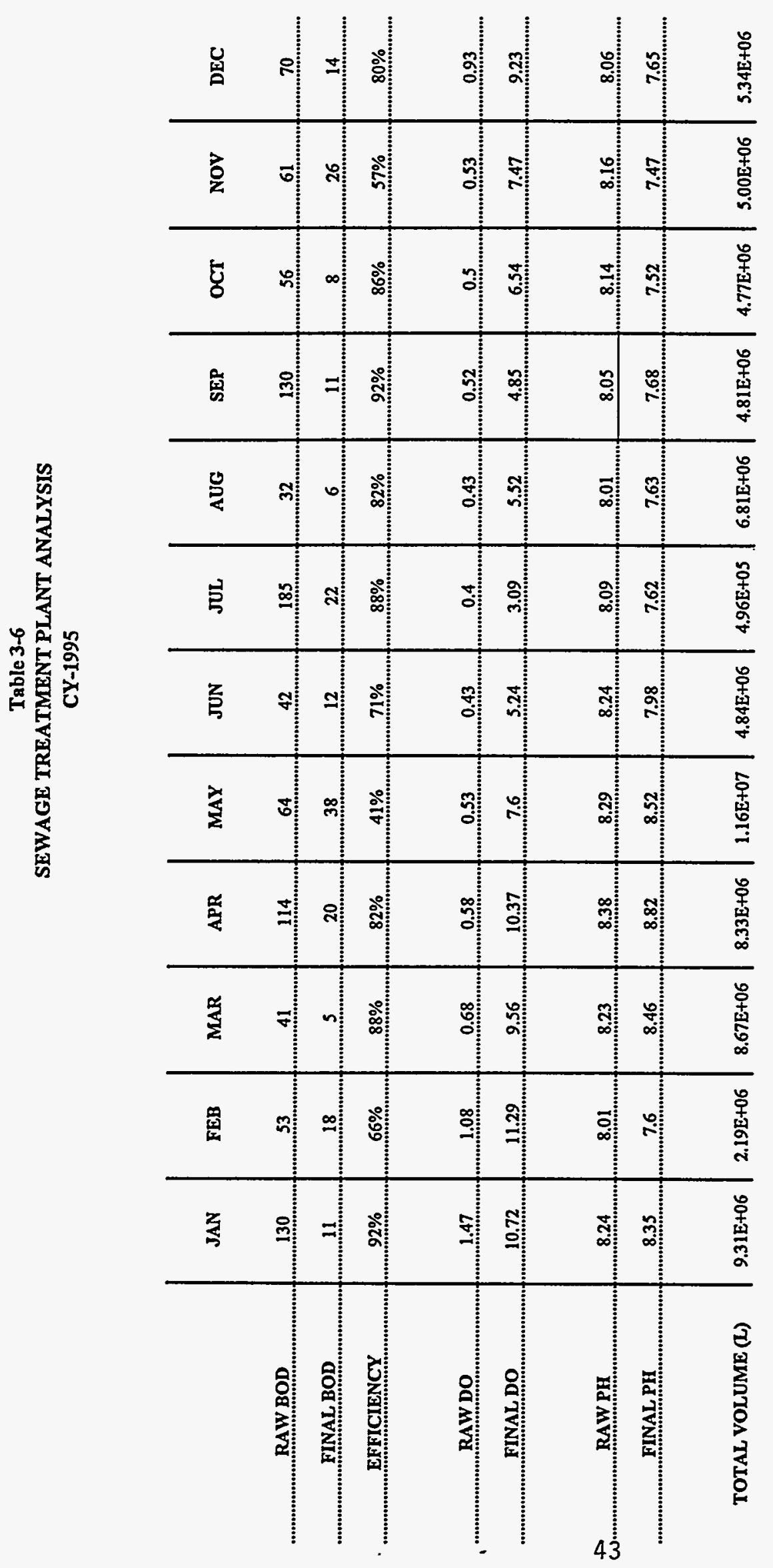




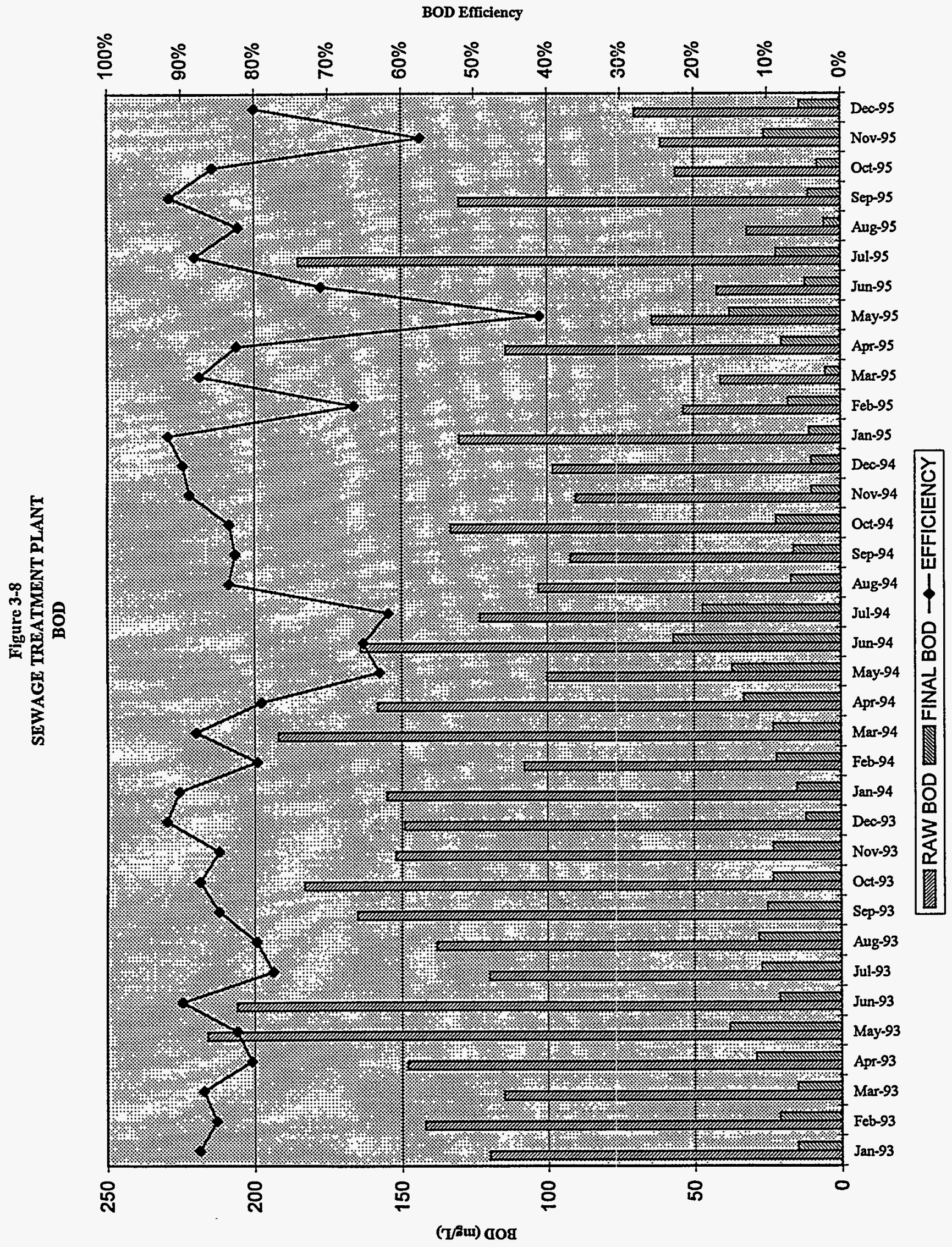




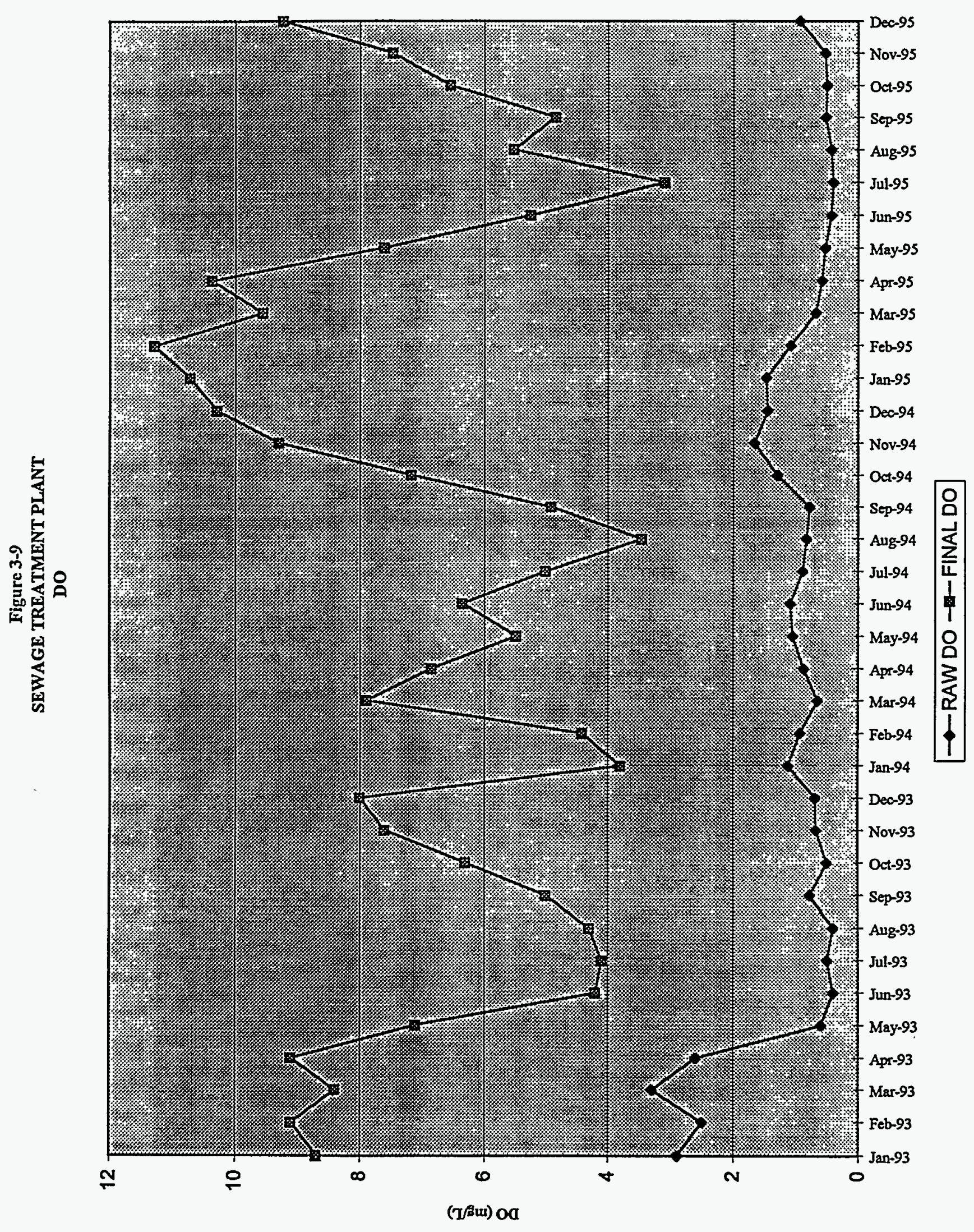




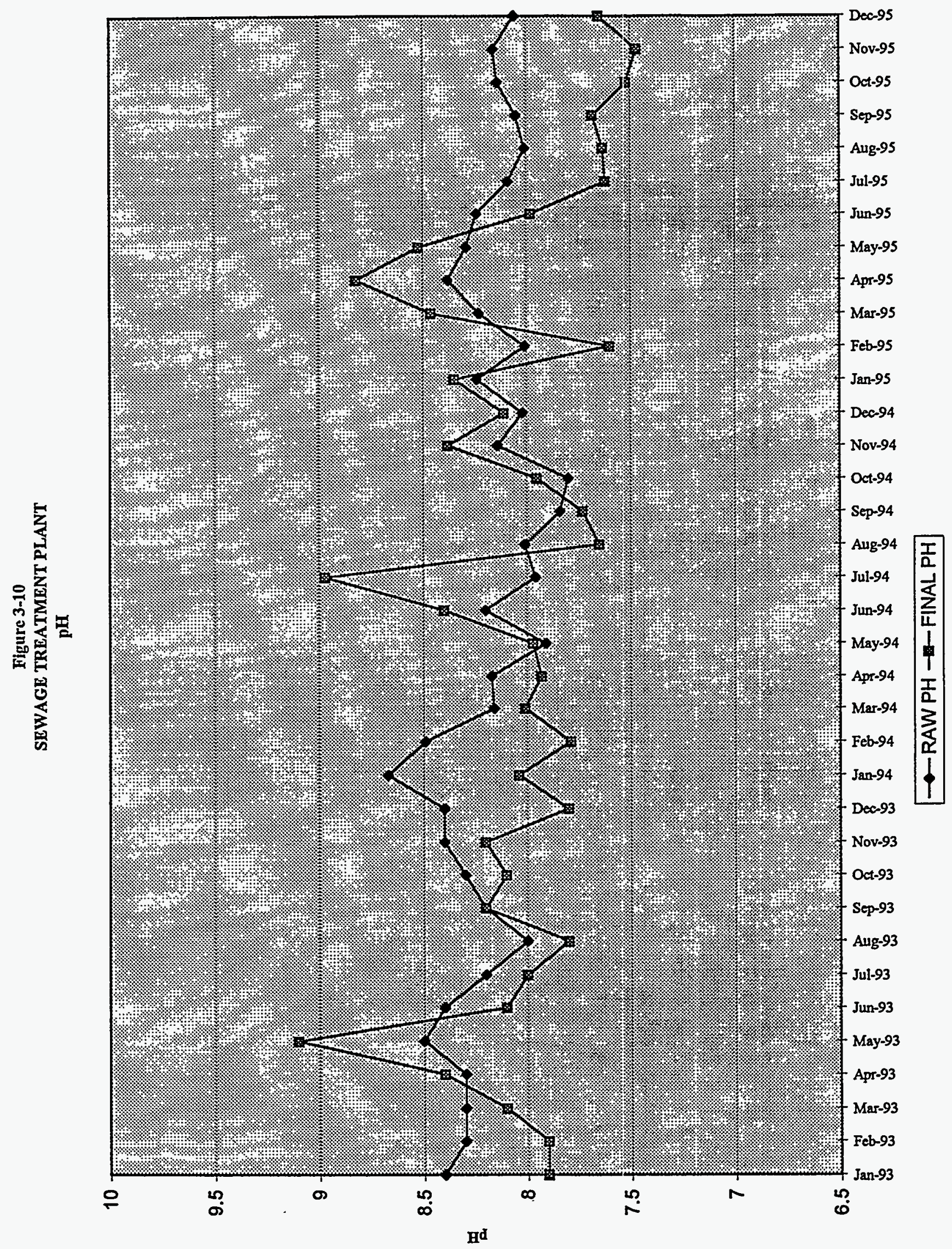




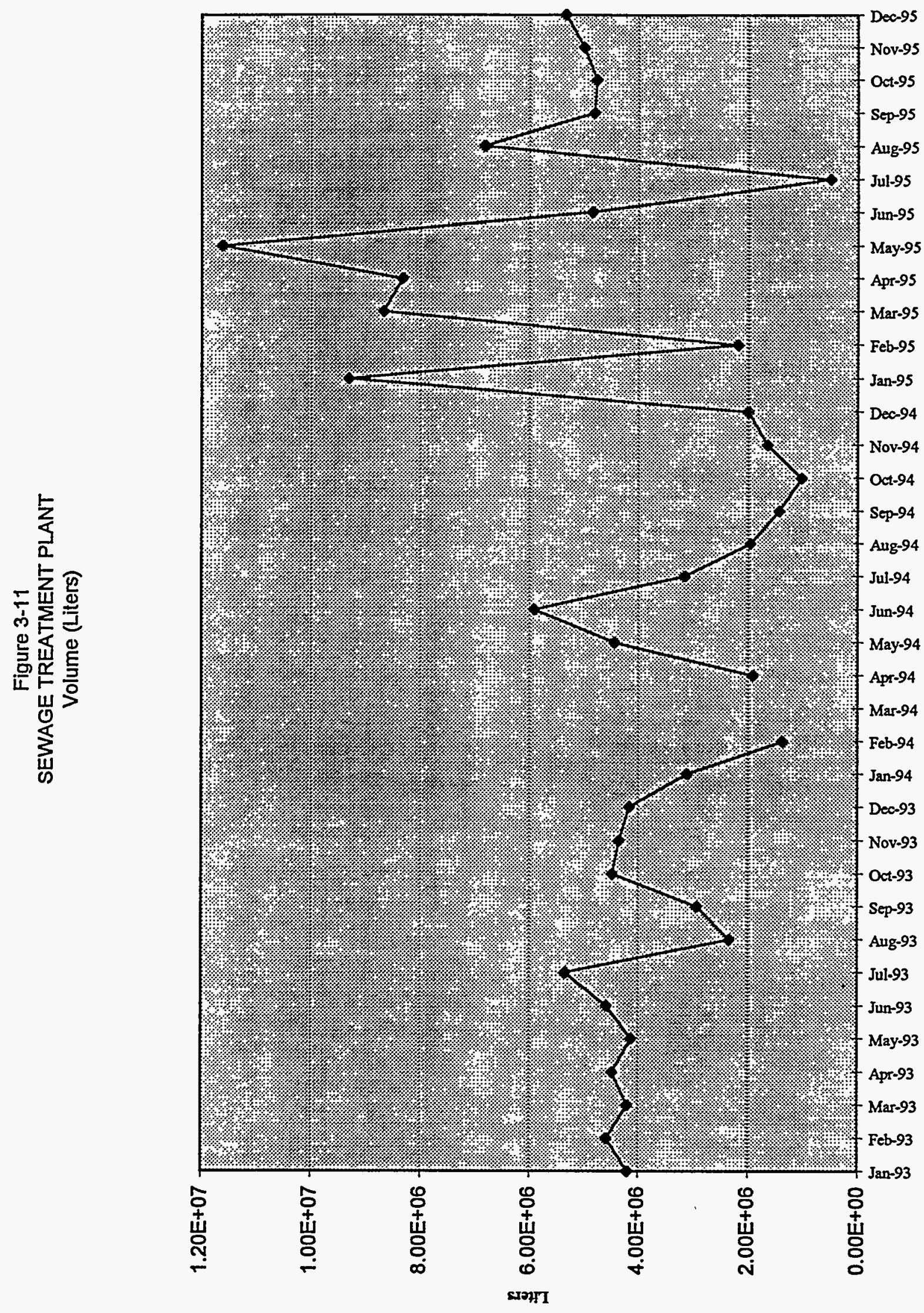

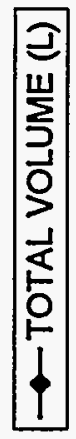


DISTRIBUTION

C. W. Bingham

T. W. Chesnovar

I. R. Dausin

S. F. Henderson

E. R. McMahaen

J. K. Neff (10)

D. J. Wiggins

D. E. Walker

ERC (2) 
